\title{
The influence of chronic conditions and the environment on pubertal development. An example from medieval England
}

Article

Accepted Version

Creative Commons: Attribution-Noncommercial-No Derivative Works 4.0

Lewis, M. E., Shapland, F. and Watts, R. (2016) The influence of chronic conditions and the environment on pubertal development. An example from medieval England. International Journal of Paleopathology, 12. pp. 1-10. ISSN 1879-9817 doi: https://doi.org/10.1016/j.ijpp.2015.10.004 Available at https://centaur.reading.ac.uk/51151/

It is advisable to refer to the publisher's version if you intend to cite from the work. See Guidance on citing.

To link to this article DOI: http://dx.doi.org/10.1016/j.ijpp.2015.10.004

Publisher: Elsevier

All outputs in CentAUR are protected by Intellectual Property Rights law, including copyright law. Copyright and IPR is retained by the creators or other copyright holders. Terms and conditions for use of this material are defined in the End User Agreement.

www.reading.ac.uk/centaur 
Central Archive at the University of Reading

Reading's research outputs online 
The influence of chronic conditions and the environment on pubertal development. An example from medieval England.

Corresponding author:

Dr Mary E Lewis, Department of Archaeology, SAGES, University of Reading, Whiteknights, Reading RG6 6AB, UK

Phone: +44 118-378-8927

m.e.lewis@reading.ac.uk 
The influence of chronic conditions and the environment on pubertal development. An example from medieval England.

Lewis, ME, Shapland, F and Watts, R

\section{Abstract}

Adolescence is a unique period in human development encompassing sexual maturation (puberty) and the physical and psychological transition into adulthood. It is a crucial time for healthy development and any adverse environmental conditions, poor nutrition, or chronic infection can alter the timing of these physical changes; delaying menarche in girls or the age of peak height velocity in boys. This study explores the impact of chronic illness on the tempo of puberty in 607 adolescent skeletons from medieval England (AD 900-1550).

A total of 135 (22.2\%) adolescents showed some delay in their pubertal development, and this lag increased with age. Of those with a chronic condition, $40.0 \%$ ( $n=24 / 60)$ showed delay compared to only $20.3 \%(n=111 / 547)$ of the non-pathology group. This difference was statistically significant. A binary logistic regression model demonstrated a significant association between increasing delay in pubertal stage attainment with age in the pathology group.

This is the first time that chronic conditions have been directly associated with a delay in maturation in the osteological record, using a new method to assess stages of puberty in skeletal remains.

Keywords: tuberculosis, treponemal disease, rickets, epiphyseal fusion, adolescence

\section{Introduction}

Today, adolescence (from the Latin 'adolescere', or "to grow up") is defined by the World Health Organisation (1993) as a period between the ages of 10 to 24 years.

Adolescence is a crucial period in terms of healthy development when individuals gain $50 \%$ of their weight and $20 \%$ of their final adult stature (World Health Organisation 1993). This adolescent growth spurt is a uniquely human phenomenon and encompasses sexual maturation (puberty), marking a period of physiological and psychological transition into adulthood (Hochberg and Belsky 2013). Adolescent health is receiving increasing attention in modern populations, with their unique behaviour directly linked to morbidity. Alcohol abuse, drug-taking and sexual activity increases the risk of unwanted pregnancies, sexually transmitted diseases and deaths due to motor vehicle accidents and suicides (Grunbaum et al., 2004). Well-nourished and healthy adolescent females are seen as the key for overall population well-being, with the nutritional levels of women before their first pregnancy having a direct impact on the development and birth-weight of their child and its subsequent survival (EWEC 2015). Despite the importance of this period of human development, it has received scant attention in bioarchaeology. 
Pubertal changes occur as the result of stimulation of the hypothalamic-pituitarygonadal (HPG) axis and the hypothalamic-pituitary-adrenal (HPA) axis (Louis et al. 2008). The latter, although active during infancy, becomes latent during childhood and is reactivated by the release of gonadotropine into the hypothalamus during adolescence, stimulating the gonads. Sex steroid induced accelerated growth is in turn, reliant on the presence of insulinlike growth factors produced by the pituitary gland (or the GH/IGF-1 axis) (Mason et al. 2011). Within a year of peak height velocity (PHV) being reached, girls will menstruate indicating that the ovaries are capable of secreting sufficient levels of oestrogen. Sometime later, the brain emits neuro-endocrine signals in a 26-day cycle that stimulates the pituitary glands to release the hormones needed for ovulation (Zacharias and Wurtman 1969). In boys, the presence of gonotrophins stimulate the release of androgens (testosterone and androstenedione), a stage known as 'gonadarch' (Louis et al. 2008). The HPA axis is independent of HPG and signals adrenal activation, eventually stimulating the formation of secondary sexual characteristics (Louis et al. 2008), such as breast development in females, and the apperance of facial hair and voice 'breaking' in males.

Many factors have been shown to influence the onset of puberty, including genetic disorders, ancestry, social status, nutrition, exposure to pollutants, extreme physical exercise, psychological stress, increased or reduced body mass, and chronic illness (Louis et al. 2008). Successful progression through the pubertal stages relies on the height and weight of the individual, which in turn is influenced by nutrition and the absence of chronic disease (Proos and Gustafsson 2012). Hochberg and Belksky (2013) interpret this relationship in terms of evolutionary biology, demonstrating phenotypic adaptive plasticity in favourable environmental conditions that allow females to achieve the extremes of their genetic range for maturation. In less favourable conditions, females may delay sexual maturation until they have reached the required body weight, providing for later fecundity, fertility and greater longevity. In terms of health longer term, the importance of pubertal growth on peak bone mineral density is demonstrated by the observation that women who experience delayed menarche by as little as two years, are more vulnerable to bone loss before the age of 40 years and potentially, early osteoporosis (Karapanou and Papadimitriou 2010).

Adolescence is a time of increased susceptibility to chronic infections such as tuberculosis and leprosy, due to exposure to new diseases associated with a riskier lifestyle, and the maturation of the immune system (Marais et al. 2005; Patil 2013). The greater propensity for adolescents over younger children to develop chronic tuberculosis for instance, is explained by Marais et al. (2005). They point to the destructive containment of pathogens, characteristic of a maturing immune response, as producing an oxygen-rich environment that allows $M$. tuberculosis to flourish, producing adult-type cavitations in the lung tissue. Chronic bowel conditions such as Crohn's disease and colitis often manifest in early adolescence and are associated with a delay in puberty development, and in particular delay boys entering peak height velocity of the adolescent growth spurt (Proos and Gustafsson 2012). This is though to be due to the combined influence of poor nutrition and inflammation on the GH/IGF-1 axis (Mason et al. 2011). Juvenile idiopathic arthritis is 
another condition that often develops around 11-14 years, and is associated with a delay in puberty due to chronic inflammation, with menarche often occurring two years later than in healthy adolescents (Tsatsoulis et al. 1999; Umlawska and Prusek-Dudkiewicz 2010). Stini (1985: 213) also argued that the difference in immune system capability between males and females arises during adolescence as female bodies prepare for pregnancy.

While the presence of chronic infections is known to delay pubertal attainment in modern populations, this has yet to be assessed in archaeological samples. The development of new osteological techniques to identify stages of puberty provides the potential for us to explore this important period of human development in much greater detail than ever before (Shapland and Lewis 2013, 2014). Recent analysis of 645 skeletons aged between 10-25 years from medieval England provided the first direct evidence for the age of the adolecent growth spurt and onset of puberty between the seventh to sixteenth centuries (Lewis et al. 2015). While both males and females began puberty around 10-12 years, as today, the tempo of pubertal growth was longer, with females achieving menarche between 13-16 years, and individuals being as old as 16-20 years before they were fully mature. In London, most females were not achieving menarche until they were 17 years of age, and many were dying between 22-25 years, before they have reached full maturation. These delays indicate that the age at which children achieve each maturational stage in adolescence may be useful as an indicator of environmental stress.

During that study it was noted that a number of children identified as being behind their peers in pubertal stage attainment also suffered from a chronic condition, including tuberculosis, treponemal disease, osteomyelitis, rickets, bowel infection, arm paralysis and severe congenital spinal curvature (Lewis et al. 2015). The current study explores this association in more detail to assess the impact of chronic conditions on the tempo of the adolescent growth spurt, peak height velocity and menarche in urban medieval England.

\section{Materials and methods}

Of the original study sample of 994 adolescent individuals (10-25 years) analysed by Shapland and Lewis (2013; 2014), 607 were preserved well enough for a pubertal stage and the presence or absence of a pathology to be observed with confidence and were included in the analysis. This medieval urban sample comprised skeletons from four cemetery sites in England dating from AD 900-1550; St Peter's Church, Barton-on-Humber (or Barton, $n=109$ ), a combined York sample of St. Helen-on-the-Walls and Fishergate House $(n=71)$, with the majority derived from St Mary Spital, London ( $n=427$ ) (Figure 1). The adolescents from Barton were considered to be relatively affluent in comparison to those from York and London (Tyszka 2006), and it is likely the London sample contained a more diverse migrant group (Connell et al. 2012). As the focus was on the physical development of individuals with chronic conditions rather than geographical location or social status, the samples were combined to represent one large urban medieval sample. 


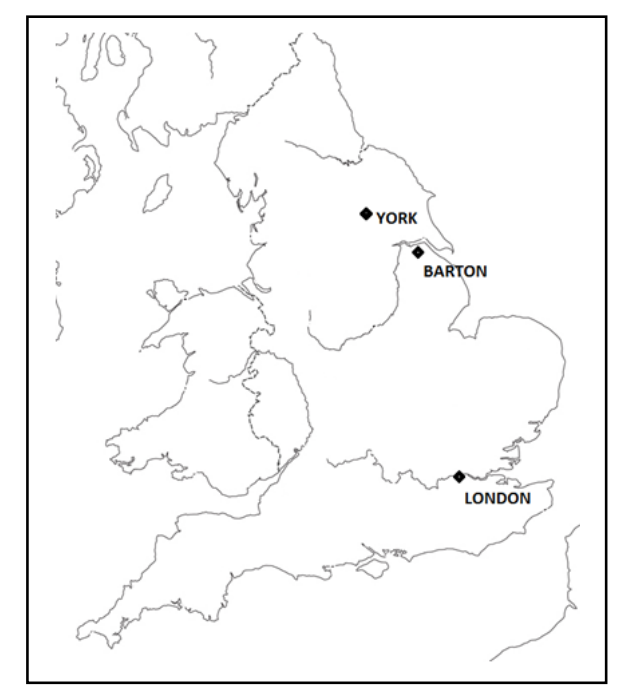

Figure 1. Location of the cemetery sites used in the study

\subsection{Age and sex determination}

In order to investigate the influence of skeletal pathology on adolescent development in the largest sample possible, individuals were each assigned a 'minimum' age (i.e. 14+ years, 17+ years etc.) based on the lowest estimates derived from their dental age or extent of skeletal maturation. Age was assessed independently of pubertal status, with any marker used to provide a pubertal stage (e.g. the canine, iliac crest fusion, radial fusion etc.) omitted from the age assessment. For the dentition, age-at-death was determined using ages of attainment for the calcification of the permanent mandibular dentition (Moorrees et al. 1963 , tabulated in Scheuer and Black, 2000). A mean age was calculated by averaging the ages for all observed teeth, combining the male and female values where sex was unknown. When only the third molar was still developing, a mean age was assigned using Liversidge and Marsden (2010), with the mean value taken as the minimum age. Once dental development was complete, age was assigned based on skeletal maturation. Observations were based on fusion of the proximal humerus, proximal and distal tibia and femur; extension of the epiphysis of the ischio-pubic ramus; flaked epiphysis at the medial clavicle, fusion of the ischial epiphysis, sacrum and vertebral annular rings (Albert and McCallister 2004; Schaefer et al. 2009). Anyone with a fused S1-S2 junction or fused medial clavicle epiphysis was considered to be over 25 years of age and was excluded from the study sample. The assigned minimum age was used to assess any delay in pubertal attainment for each individual.

Where possible, a sex assessment was carried out for all individuals aged 10-25 years (Lewis et al. 2015). The youngest groups were sexed using traits that have been shown to provide between $70 \%$ to $85 \%$ accuracy or above on the distal humerus, mandible and ilium (Falys et al. 2005; Sutter 2003). Sex was assigned only when three of these estimates agreed, from at least two different areas (i.e. features from the ilium and humerus). After 15 years, standard methods to sex adults based on the pelvis were employed (Buikstra and Ubelaker 1994), although the cranium was only used to confirm a male assignment, to avoid problems of effeminate cranial morphology noted in younger males (Walker 1994).

\section{$\underline{2.2 \text { Assessing pubertal stage from skeletal and dental markers }}$}


The changes associated with the adolescent growth spurt follow a regular pattern that in clinical practice is identified through a series of 'bone markers' (Tanner et al. 1975). First, skeletal growth accelerates until 'peak height velocity' (PHV) is reached (Marshall and Tanner 1986). Around one year after PHV, during the deceleration phase, girls will achieve menarche and boys develop a full adult voice (Hägg and Taranger 1982). The growth spurt ends with the fusion of the major long bone epiphyses and complete maturation is signalled by fusion of the iliac crest (Marshall and Tanner 1986). Shapland and Lewis (2013; 2014) and Lewis et al. (2015) provide a series of bone markers that can be applied to human skeletal remains in order to assess an individual's position within the adolescent growth spurt and pubertal maturation sequence. Following these methods, observations were made using the mandibular canine root, the cervical vertebrae, bones of the hand, elbow and wrist, and maturation of the iliac crest. A pubertal stage was only assigned where three or more features were in agreement. Two stages of development were of particular interest for this study of puberty and health and are outlined below.

\subsubsection{Peak height velocity}

Peak height velocity is a crucial developmental stage in adolescence. In boys it signals a corresponding increase in weight and musculature that improves their physical capacity (Philippaerts et al. 2006). In girls, PHV corresponds to an increase in breast size signalling their transition to womanhood (Marshall and Tanner 1969). This stage provides the development of the external secondary sexual characteristics of adulthood and may have promoted a change in the way individuals were perceived by their society. Peak height velocity in particular has been found to be delayed in the presence of chronic inflammatory disease, especially in boys (Proos and Gustafsson 2012). Peak height velocity was estimated to have been achieved (either at or past PHV) when the following features were present:

- Hook of hamate complete: Stage I occurs around six months before PHV (Grave and Brown 1976),

- Canine Stage G (root complete or apex 1/2): occurs between 0.4 years and 1.3 years before PHV in girls and boys, respectively (Coutinho et al. 1993).

- Cervical vertebral maturation at Stages 3 and 4 (Franchi et al., 2000; Shapland and Lewis, 2014).

- Fusion of the proximal ulna, capitulum of the humerus and phalangeal epiphyses: fusion of the proximal ulna epiphysis precedes PHV (Roche 1976), fusion of the phalangeal epiphyses and capitulum at the lateral distal humerus occurs shortly after PHV (Houston 1980; Roche 1976).

\subsubsection{Menarche}

Menarche is a standard measure of adolescent development in clinical practice and the historical data, and precedes fertility in women by about a year (Zhang et al. 2008). Studies have consistently shown a link between poor nutritional status and a delay in menarche regardless of the child's ancestry or climate (Gluckman and Hanson 2006; Goyal et al. 2012; 
Zacharias and Wurtman 1969). Given the intricate link between malnutrition and disease, the age at which menarche was achieved in our medieval samples was estimated as follows (Buehl and Pyle 1942; Frisancho et al. 1969):

- Presence of an ossified iliac crest epiphyses or fusion (of any part) of the crest,

- Fusion of the distal phalanx of the second finger where possible or in lieu of this, fusion of any distal hand phalanges.

\subsection{Assessment of chronic conditions}

Any sign of a chronic condition was noted in the sample. In particular, tuberculosis (TB) was diagnosed when an individual displayed classic lytic spinal changes, with or without collapse (Pott's disease), which may be accompanied by widespread new bone formation on the ribs and long bones (Lewis 2011). Treponemal disease (e.g. endemic and venereal syphilis) was diagnosed with the presence of gummatous lesions on the skull and long bones (Buckley and Dias 2002). Osteomyelitis, evident through the presence of a cloaca, involucrum and sequestrum (Ortner 2003), was also taken as evidence for long term ill-health. In addition to chronic infections, individuals with a metabolic disease (i.e. rickets, scurvy, porotic hyperostosis), or severe congenital conditions were identified using the criteria set out by Brickley and Ives (2008) and Ortner (2003).

In order to test whether individuals harbouring chronic conditions were significantly delayed in their development compared to those with no evidence of disease, an expected age at which each pubertal Stage should have been attained was calculated (Table 1). These ages were based on the average age range of Stage attainment for medieval adolescents calculated by Lewis et al. (2015). In order to ensure only significantly delayed individuals were identified, the midpoint of this age range was taken for each Stage providing a generous expected age of attainment.

Table 1. Average age range (years) at which a Stage is expected to have been reached (adapted from Lewis et al. 2015).

\begin{tabular}{llll}
\hline Stage & Process & Range & $\begin{array}{l}\text { Expected age (years) } \\
\text { of attainment }\end{array}$ \\
\hline 1 & Initiation & $10-12$ & 10 \\
2 & Acceleration & $10-13$ & 12 \\
3 & PHV & $11-15$ & 14 \\
4 & Deceleration/Maturation & $15-17$ & 16 \\
5 & Completion & $16-22$ & 19 \\
\hline
\end{tabular}

The effect of a chronic condition on an individual's pubertal status, whether delayed or not delayed, was tested using a Pearson chi-squared test, and the ability to predict whether an individual with a condition would be more likely to be delayed as their age increased was assessed using a binary logistic regression model with SPSS (Peng et al. 2002). 


\section{Results}

Of the 607 individuals in the sample, 50\% were assigned a 'minimum age' based on their dental development with the rest aged based on their skeletal maturation. A total of 60 (9.9\%) displayed a chronic condition, whether metabolic, congenital or infectious. The overwhelming majority (52/60 or $86.6 \%$ ) of the affected adolescents were from the later medieval London site of St Mary Spital (Table A.1).

Of the 607, a total of 135 (22.2\%) individuals demonstrated some delay in their pubertal stage compared to the expected average age of attainment (Tables 2 and 3). In the pathology group, $40.0 \%(n=24 / 60)$ were delayed compared to a lesser $25.4 \%(n=111 / 436)$ of those in the non-pathology group. This difference in the proportion of individuals delayed in two groups was statistically significant $\left(X^{2}=11.66, P=<0.001\right.$, d.f.1).

When the general pattern of pubertal attainment was compared between the pathology and non-pathology groups (Figures 2ab), it showed that while adolescents are all entering the acceleration phase of the growth spurt around the same age, and over a similar wide period of time, those with a chronic conditions appear to lag behind their healthier peers at PHV. When the delayed group (pathology and non-pathology individuals) was examined as a whole (Figure 3 ), this lag increased as individuals proceeded through the pubertal stages, being most evident at PHV (Stage 3) and Completion (Stage 5).

Table 2. Minimum age, sex and pathology status of the non-delayed group.

\begin{tabular}{|c|c|c|c|c|c|c|}
\hline $\begin{array}{l}\text { Minimum } \\
\text { Age }\end{array}$ & Num & of Indivi & als & 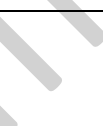 & Pathology & tatus \\
\hline & Male & Female & Not sexed & Total & Yes & No \\
\hline 10 & 16 & 14 & 21 & 51 & 1 & 50 \\
\hline 11 & 15 & 7 & 14 & 36 & 3 & 33 \\
\hline 12 & 9 & 4 & 6 & 19 & 3 & 16 \\
\hline 13 & 20 & 5 & 12 & 37 & 2 & 35 \\
\hline 14 & 3 & 12 & 23 & 38 & 3 & 35 \\
\hline 15 & 28 & 14 & 22 & 64 & 7 & 57 \\
\hline 16 & 21 & 12 & 7 & 40 & 1 & 39 \\
\hline 17 & 40 & 18 & 4 & 62 & 5 & 57 \\
\hline 18 & 12 & 12 & 0 & 24 & 0 & 24 \\
\hline 19 & 6 & 7 & 0 & 13 & 0 & 13 \\
\hline 20 & 4 & 9 & 0 & 13 & 0 & 13 \\
\hline 21 & - & - & - & 0 & - & - \\
\hline 22 & 51 & 24 & 0 & 75 & 11 & 64 \\
\hline Total & 225 & 138 & 109 & 472 & 36 (7.6\%) & $436(92.3 \%)$ \\
\hline
\end{tabular}


Table 3. Minimum age, sex and pathology status of the delayed puberty group.

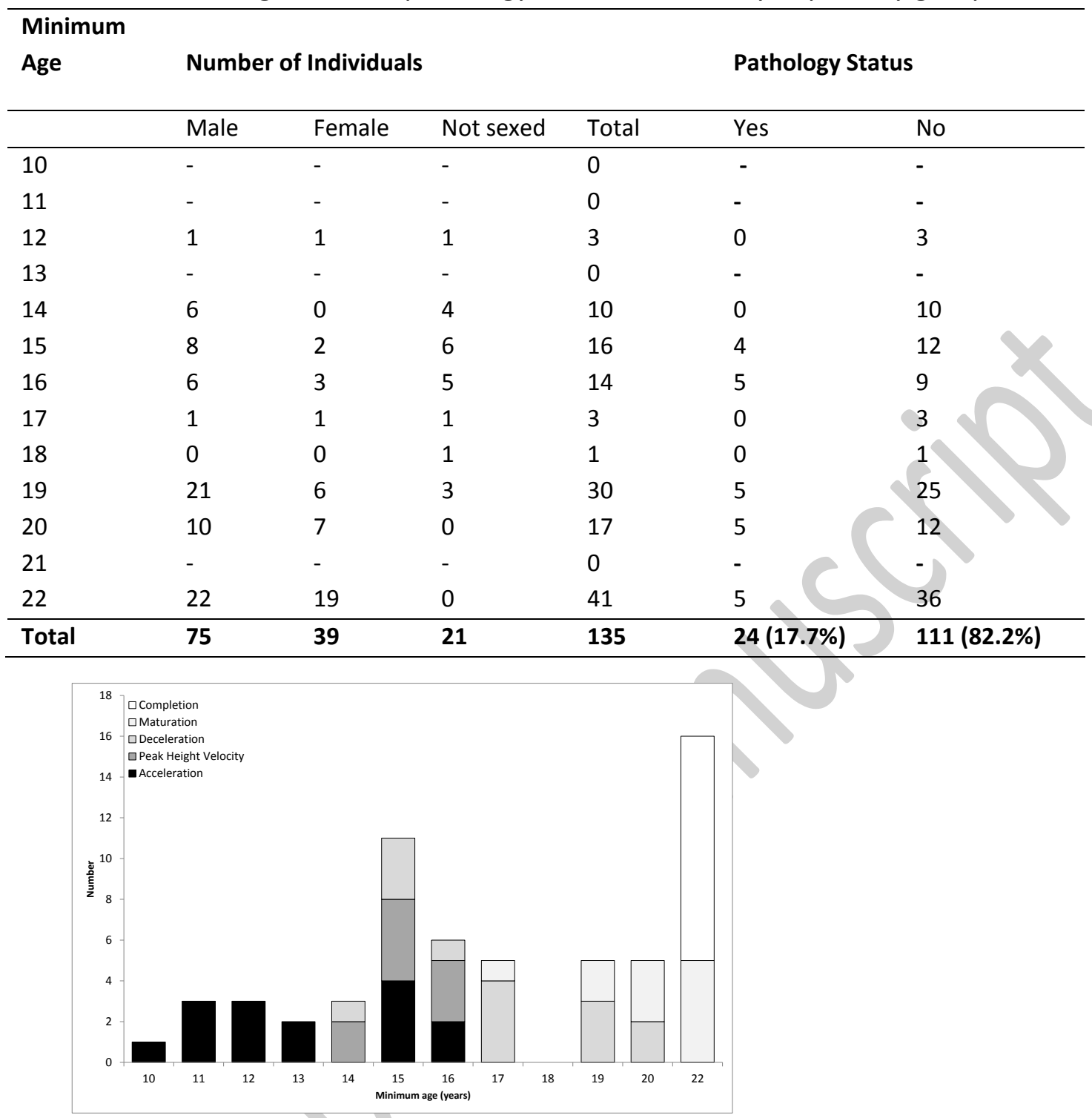

Figure $2 a$ Age of pubertal stage attainment in non-pathology group $(n=547)$

Figure $2 b$ Age of pubertal stage attainment in the pathology group $(n=60)$

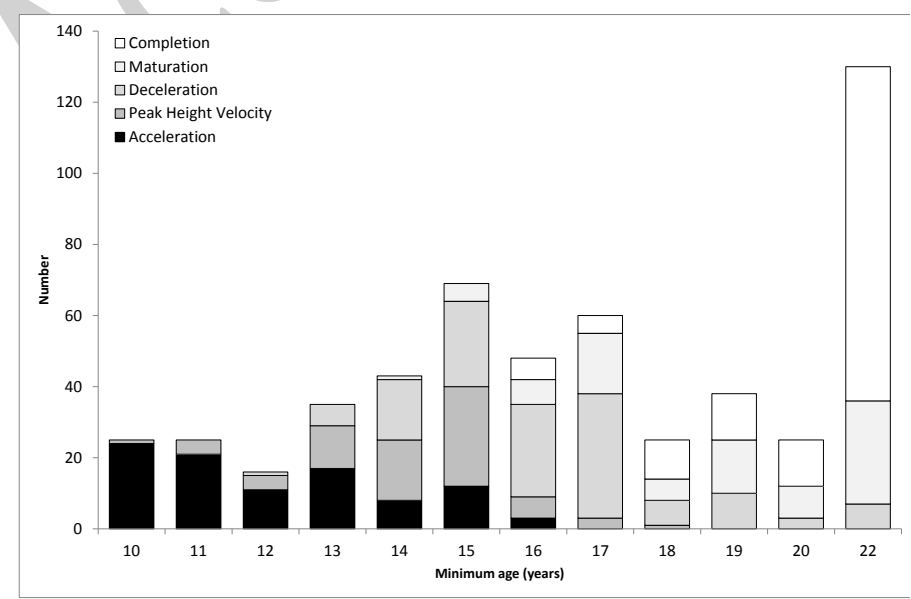


It is possible that the onset of the infectious disease or metabolic condition occurred after a pubertal stage had been reached in an individual and would therefore have had no impact on stage progression. For this reason, the stage attainment of the 47 individuals with identifiable chronic conditions was examined more closely (Tables 4-6). There were 19 clear cases of tuberculosis and treponemal disease, 16 individuals were probably suffering from either rickets or scurvy based on severe bowing of the long bones, frayed metaphyseal ends, porotic hyperostosis, or widespread new bone formation. Another 12 adolescents suffered from congenital conditions that may have affected their normal development or access to resources. Perthe's disease and slipped femoral epiphyses are included in the congenital group, despite their more complex aetiology including a circulatory disorder or traumatic event (Ortner, 2003), as both may have affected the physical ability of these individuals.

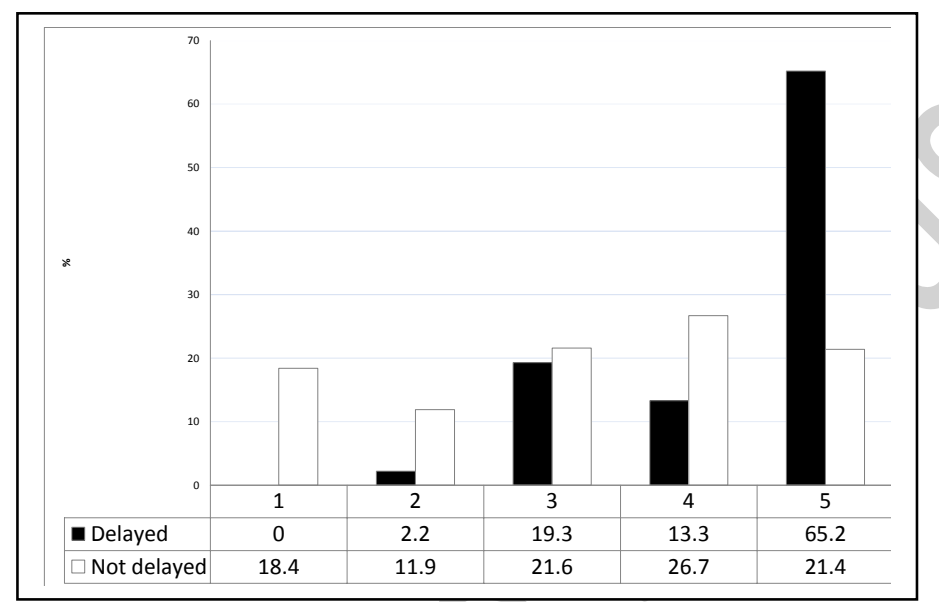

Figure 3. Percentage of individuals delayed at each stage of pubertal development.

Table 4: Pubertal development of adolescents with tuberculosis and treponemal disease, ordered by age (years). SP: St Mary Spital; B: Barton; Y: York. Delayed individuals are highlighted in bold.

\begin{tabular}{llllll}
\hline Skeleton & $\begin{array}{l}\text { Minimum } \\
\text { age }\end{array}$ & Condition & Sex & Pubertal stage & Delayed? \\
\hline SP30702 & 11 & Tuberculosis & M? & Acceleration & No \\
SP25618 & 12 & Tuberculosis & & Acceleration & No \\
Y1205 & 13 & Tuberculosis & M? & Acceleration & Yes \\
SP27615 & 14 & Tuberculosis & & Deceleration & No \\
SP13715 & 15 & Treponematosis & M? & Deceleration & No \\
SP29986 & 15 & Tuberculosis & & PHV & Yes \\
SP22829 & $\mathbf{1 5}$ & Tuberculosis & & Acceleration & Yes \\
SP20634 & 16 & Treponematosis & F? & Deceleration & No \\
SP5426 & $\mathbf{1 6}$ & Tuberculosis & & PHV & Yes \\
SP22345 & $\mathbf{1 6}$ & Tuberculosis & F? & PHV & Yes
\end{tabular}




\begin{tabular}{llllll} 
SP27544 & 16 & Treponematosis & & PHV & Yes \\
SP30931 & 16 & Tuberculosis & F & Acceleration & Yes \\
SP7571 & 19 & Treponematosis & F & Maturation & Yes \\
SP3975 & 20 & Tuberculosis & M & Deceleration & Yes \\
SP22542 & 20 & Tuberculosis & M & Deceleration & Yes \\
SP3144 & 22 & Tuberculosis & F & Maturation & Yes \\
SP15030 & 22 & Tuberculosis & F & Post & No \\
SP13232 & 22 & Treponematosis & F? & Maturation & Yes \\
SP15575 & 22 & Tuberculosis & F & Maturation & Yes \\
\hline
\end{tabular}

Table 5: Pubertal development of adolescents with possible metabolic conditions, ordered by age (years). SP: St Mary Spital; B: Barton; Y: York. Delayed individuals are highlighted in bold.

\begin{tabular}{llllll}
\hline Skeleton & age & Condition & Sex & Pubertal stage & Delayed? \\
\hline SP24009 & 10 & Porotic hyperostosis & M? & Acceleration & No \\
Y1518 & 11 & Rickets & M? & Pre-puberty & No \\
SP3933 & 11 & Probable scurvy & & Pre-puberty & No \\
B810 & 12 & Rickets & M? & Acceleration & No \\
B961 & 14 & Probable rickets & M? & Deceleration & No \\
SP3861 & 14 & Rickets & F & Deceleration & No \\
Y1577 & $\mathbf{1 5}$ & Probable rickets & & PHV & Yes \\
SP2622 & 15 & Porotic hyperostosis & & PHV & Yes \\
SP15255 & 15 & Probable scurvy & F? & Acceleration & Yes \\
SP32355 & 15 & Probable scurvy & M & Deceleration & No \\
B704 & 16 & Rickets & & Maturation & No \\
SP15669 & 16 & Probable rickets & F? & Deceleration & No \\
SP17072 & 17 & Probable rickets & M? & Maturation & No \\
B131 & 19 & Rickets & F & Complete & No \\
Y5409 & 22 & Probable rickets & M & Complete & No \\
SP29152 & $\mathbf{2 2}$ & Probable rickets & M & Maturation & Yes \\
\hline
\end{tabular}

Table 6: Pubertal development of adolescents with congenital conditions, ordered by age (years). SP: St Mary Spital; B: Barton. Delayed individuals are highlighted in bold.

\begin{tabular}{llllll}
\hline Skeleton & $\begin{array}{l}\text { Minimum } \\
\text { age }\end{array}$ & Condition & Sex & Pubertal stage & Delayed? \\
\hline SP13829 & 12 & $\begin{array}{l}\text { Familial idiopathic } \\
\text { hyperphosphatia }\end{array}$ & M? & Acceleration & No \\
SP2917 & 13 & $\begin{array}{l}\text { Radial aplasia } \\
\text { Hyperbrachycephaly }\end{array}$ & F? & PHV & No \\
SP29964 & 15 & Deceleration & No
\end{tabular}




\begin{tabular}{|c|c|c|c|c|c|}
\hline SP12538 & 17 & Tarsal coalition & M & PHV & Yes \\
\hline SP20417 & 17 & Talipes equinovarius & $M ?$ & Maturation & No \\
\hline SP27661 & 17 & $\begin{array}{l}\text { Vertebral hypoplasia and } \\
\text { kyphosis }\end{array}$ & $M$ & Deceleration & No \\
\hline SP32178 & 18 & Tarsal coalition & $M ?$ & Deceleration & No \\
\hline SP3816 & 22 & Ulna dysplasia (glenoid) & M & Complete & No \\
\hline SP20157 & 22 & Scaphocephaly & $\mathbf{F}$ & Deceleration & Yes \\
\hline SP31395 & 22 & Perthe's disease & M & Complete & No \\
\hline B1312 & 22 & Spina bifida & M & Complete & No \\
\hline B2340 & 22 & $\begin{array}{l}\text { Slipped femoral } \\
\text { epiphysis }\end{array}$ & M & Complete & No \\
\hline
\end{tabular}

In the chronic infection group, 13 (68.4\%) of the adolescents showed delay in their pubertal stage attainment compared to what might be expected for their age. Of the 14 individuals with tuberculosis, $71.4 \%(n=10)$ were delayed, compared to $60.0 \%(n=3 / 5)$ of those with treponematosis. For the metabolic group, four (25.0\%) were showing delay compared to two (16.7\%) individuals with congenital conditions. When these groups were compared, delay was significantly more likely to occur in individuals with an infectious disease, than in the metabolic and congenital group $\left(X^{2}=10.04, P=<0.01\right.$, d.f.2).

The general impression from these data is that as individuals grew older, the impact of the pathology exacerbated their delay, with chronically ill individuals falling further behind their healthier peers. In order to test whether this pattern was significant and could be predicted, a binary logistic regression model was applied to the data. The results are provided in Table 7 . They show that increasing age is significantly associated with being delayed (the dependant), with individuals lagging further behind in the pubertal stage as they get progressively older, and that this pattern is more significant in individuals who have a pathological condition, than those who do not $(P=0.005)$.

Table 7. Predicted probability of being delayed in pubertal development with increasing age when suffering from a chronic condition

\begin{tabular}{lllllll}
\hline & Predictor & B(SE) & Wald's $\boldsymbol{X}^{\mathbf{2}}$ & df & Significance & $\begin{array}{l}\text { exp }^{\boldsymbol{B}} \text { (odds } \\
\text { ratio) }\end{array}$ \\
\hline Step 1 & Delayed (dependant) & $5.20(0.55)$ & 58.99 & 1 & 0.000 & 181.79 \\
& Minimum age & $-0.23(0.03)$ & 90.16 & 1 & 0.000 & 0.79 \\
Step 2 & Delayed (dependant) & $4.40(0.61)$ & 52.09 & 1 & 0.000 & 81.79 \\
& Minimum age by & $0.85(0.30)$ & 7.79 & 1 & 0.005 & 2.34 \\
& pathology status & & & & & \\
\hline
\end{tabular}

\subsection{Attaining peak height velocity and menarche}

The pubertal stage PHV could be assigned to 85 individuals (including 13 females and 41 males). If 14 years is taken as the average minimum age for which PHV should be reached 
(Table 1), then 31 adolescents were delayed, representing $21.9 \%(n=25 / 114)$ of the nonpathology group and $42.8 \%(n=6 / 14)$ of the pathology group, but this difference was not statistically significant $\left(X^{2}=2.63\right.$, d.f. $\left.1, P=0.10\right)$. Only 18 of these individuals could be sexed, but it is interesting to note that in the non-pathological group, 14 of the 15 sexed individuals who were delayed for PHV were male.

Of the 355 females for whom a minimum age could be assigned, whether menarche had been passed could be estimated in 154 cases based on the maturation of the iliac crest and bones of the hand. Of these, 134 were in the non-pathology group and 20 had a chronic condition. In both groups, the youngest minimum age of menarche was 14 years, and one female in the non-pathology group showed the greatest delay having yet to reach menarche at least 17 years. If menarche is reached around 12 months after PHV, then the expected age of attainment is 15 years. No females in the pathology group for whom this status could be assessed, demonstrated delayed menarche.

\section{Discussion}

This study aimed to assess the affect of chronic conditions on pubertal development in a large group of adolescent skeletons from medieval England. The majority of individuals with pathology came from the later medieval contexts of St Mary Spital in London is not surprising given the highly industrial nature of the capital at the time. The London group would have been genetically diverse, with individuals migrating to London from rural areas in the UK and from Continental Europe (Wareing 1980; Youngs 2006), and it is also likely that both Barton and York experienced an influx of immigrants, although to a lesser extent (Goldberg 1992). Given the importance of genetics on the timing of maturation, and in particular menarche, generous average ages were provided for individuals to reach the specific stages along the puberty maturation scale. Although individuals were aged independently of the features used to assess puberty stage, skeletal maturation and pubertal development are inextricably linked, as both are affected by environmental and genetic factors. Hence, pubertal maturation provides a detailed map of maturational delay for each individual. The results indicated that a number of individuals took longer to reach the later stages of pubertal development, and this was particularly true for those suffering from a chronic condition.

The general lag of pubertal attainment with age may be an artefact of the ageing techniques employed. The majority of individuals up to Stage 3, or PHV, were aged using dental scores (76\%, $n=178 / 234$ ) over skeletal maturation (23.9\%, $n=56 / 234)$, while after Stage 3 more individuals were provided a minimum age based on their skeletal development (67.0\%, $n=252 / 376)$. As dental ages are considered more environmentally robust than skeletal maturation, this may have resulted in an underestimation of the chronological age of the older individuals, exaggerating the amount of delay with age. While this may certainly be a factor, it does not explain the lag at PHV where $60 \%$ of individuals were dentally aged, or provide an explanation for the greater delay in the pathology group. For the latter, it indicates that the presence of a chronic condition was delaying both 
general skeletal maturation reflected in the minimum age assigned, and pubertal development. Assigning a chronological age to these archaeological groups becomes particularly problematic when trying to compare their ages of pubertal attainment to that of modern children whose age is known rather than estimated, and this should be done with caution. Equally, the adolescents in this study are the non-survivors of their community, and it is possible their ages of pubertal attainment, and more importantly PHV and menarche, do not reflect the ages of pubertal attainment of the living population from which they derive. This is a common conundrum in bioarchaeology (Wood et al. 1992; Goodman 1993). It is likely, however, that the majority of the individuals in the study sample died from accidents or acute diseases that would not have affected their overall growth and development (Saunders and Hoppa 1993). Given that the expected ages of attainment were calculated using the ranges derived from the original medieval sample, rather than modern chronologies, individuals demonstrating delay are the true outliers within their peer group.

The results revealed that not only were individuals with a recognisable chronic pathology delayed in their pubertal attainment compared to their peers. This delay was particularly evident at peak height velocity and for completion. Where the individuals could be sexed, the majority of individuals failing to reach PHV by the expected time were male (77.8\%, $n=14 / 18)$ regardless of their pathological status. When these individuals were examined in detail, those suffering from the systemic chronic infections of tuberculosis or treponematosis that were the most delayed. Of the 19 individuals within this group, 13 (68.4\%) showed a delay in their pubertal stage attainment compared to what might be expected. One London female (SP30931) with TB was only in the acceleration phase of her growth spurt by 16 years compared to the average age of 13 years, and two 20-year old males (SP3975, SP22542) also from London and suffering from TB, were still in their deceleration phase when most of their peers had completed puberty (three stages ahead) by 19 years.

While the adolescents with chronic conditions provide some explanation for developmental delay beyond the average expectations for medieval adolescents, $20.3 \%$ $(n=111)$ of the delayed group showed no evidence of disease. A number will have suffered from a chronic disease that did not manifest on their skeleton before they died, for example, tuberculosis manifests in the skeleton in between 1-5\% of cases (Resnick and Kransdorf 2005; Rankin and Tuli 2009), and treponemal disease in 5-15\% (Steinbock 1976). For the rest, a series of urban environmental factors may be causing the delay in puberty attainment, and need to be considered. Strenuous child labour has associated with delayed adolescent development due to higher levels of energy expenditure (Thomas et al. 2001) and menarcheal delay has been demonstrated due to the psychological upheaval of war (Prebeg and Bralić 2000) as well as exposure to violence and fear in urban environments (Villamor et al. 2009). Malnutrition, acute infection and exposure to urban environmental pollutants may also have contributed to this pattern in these urban adolescents.

The average minimum age for menarche in medieval females was estimated at 15 years in a recent study (Lewis et al. 2015). In the current study sample, in both groups for 
whom this could be assessed, the vast majority $(98.7 \%, 152 / 154)$ experienced menarche between 14-15 years. Although not included in this study due to a lack of a definitive pubertal stage, one female from London (SP30711) died at 17.1 years (based on mean dental age) with unfused phalanges and an unfused iliac crest, suggesting she had yet to experience her menses. This female suffered from severe congenital kyphoscolosis (Walker 2012: 22). However, two females from the non-pathology group died before menarche at a mean dental age of 16.6 and 17.3. They may simply represent a normal distribution of development within the population, or it is possible that they were malnourished, or were carrying out strenuous physical activity at this critical period of their development. In modern developmental studies, age at first menarche is recorded from personal accounts of the girl or their mother, either at the time that they have their first 'period', or less accurately, from memory (Bean et al. 1979). Studies have consistently shown a link between poor nutritional status and a delay in menarche regardless of the child's ancestry or climate (Gluckman and Hanson 2006; Goyal et al. 2012; Karapanou and Papadimitriou 2010; Zacharias and Wurtman 1969). Swenne (2008) noted that girls with eating disorders and severe undernutrition were slow to progress through puberty and menarcheal delays have been demonstrated in times of famine (Van Noord and Kaaks 1991). Although carried out on a small sample of 60 North American girls, Dreizen and colleagues (1967) noted a delay in pubertal growth and menarche by as much as 24 months in undernourished girls compared to their well-nourished peers. The effects were most severe during the early stages of the adolescent growth spurt, after which 'catch-up' growth allows malnourished adolescents to achieve similar adult stature to their better nourished peers. Kaplowitz (2008) discusses the role of leptin, a protein released by fat cells, in stimulating the gonadotrophic secretion as a factor in the link between obesity in females and early menarche. A threshold level of leptin required for the initiation of menstruation suggests an evolutionary mechanism for ensuring pregnancy only occurs when an individual has achieved the right body weight (or adiposity) to ensure its success.

Karapanou and Papadimitriou (2010) argued that a delay in menarche by two years and over leaves women susceptible to developing osteoporosis at an earlier age due to a reduced peak bone mineral density at the time of maturation. While the current data has not shown any difference in menarcheal delay between the two groups under study, the onset of menarche at an average of 15 years in medieval women is three years behind modern estimates, despite starting puberty around the same age. It is possible that this later age of menarche is present in other medieval groups and may have contributed to the early bone loss in adult females identified in a later medieval site (Mays et al. 1998). Intriguingly, recent clinical studies have suggested a link between vitamin D deficiency and early menarche in females from Bogotá, Columbia (Villamor et al. 2011), and while this link has yet to be fully explained, it suggests a connection between vitamin $D$, sexual maturation and genetic variants in the oestrogen gene (Chew and Harris 2013). Of the five females diagnosed with probable rickets in the study sample and a pubertal status, one (SP3861) had reached menarche by a minimum age of 14 years, slightly earlier than her peers in 
London, but her age actually ranged between $14-18$ years so there is no evidence that we are seeing advanced pubertal development. The visibility of rickets in the archaeological record provides a tantalising glimpse into the potential of exploring vitamin $D$ status and pubertal development in skeletal remains.

Due to their rapid growth, adolescents have different nutritional requirements to the rest of the population. The iron requirement rises from $\sim 1.0$ to $2.5 \mathrm{mg} / \mathrm{d}$ in boys, due to an increased blood volume and rise in haemoglobin concentration. At peak growth, females require $\sim 1.5 \mathrm{mg} / \mathrm{d}$ iron, which finally decreases to $1.3 \mathrm{mg} / \mathrm{d}$ reflecting the need to supplement menstrual loss throughout adulthood (Brabin and Brabin 1992). Although some studies have shown iron deficiency has to be severe to affect growth (Ulijaszek 2006), others argue that iron coupled with vitamin A deficiencies may slow the tempo of growth, with any catch-up growth experienced later on in pubertal development further depleting stores of these nutrients (Brabin and Brabin 1992). Vitamin A, present in meat, poultry, fish and dairy products, fruits and vegetables is seen as essential for healthy fertility (Brabin and Brabin 1992). Acute infections such as malaria and intestinal parasites provoke a systemic response, and may affect the host over long periods of time. They can cause growth faltering due to the secondary effects undernutrition through a decreased appetite, impaired absorption or increased metabolic requirements (Ulijaszek 2006). The co-existence of disease and malnutrition have been frequently shown to cause delay in epiphyseal fusion at the end of the adolescent growth spurt, with some researchers suggesting females are less affected than males (Stini 1985).

High exposure to lead ( $3 \mu \mathrm{g} / \mathrm{dL}$ or $0.144 \mu \mathrm{mol} / \mathrm{L}$ blood levels) has been shown to delay physical growth, development and menarche, perhaps due to its affects on endocrine function (Selevan et al. 2003; Ulijaszek 2006; Wu et al. 2003). By contrast, exposure to mercury is thought to stimulate early menarche when compared to non-exposed adolescents (Denham et al. 2005). Environmental pollution had been noted in medieval urban environments since the 1250s (Bimblecombe 2011), and by the post-medieval period anthropomorphic lead levels reached as high as 90ppm (Millard et al. 2014). To explore the potential impact of generalised malnutrition, pollution and infection in the study sample, the prevalence of cribra orbitalia was used as a measure of anaemia of non-specific aetiology. Anaemia can be caused by malnutrition due to a lack of meat and leafy vegetables (resulting in iron, folic acid or vitamin B12 deficiency), as well as due to the secondary effects of lead exposure and infections such as malaria (Brown and Holden 2002; Bolton-Maggs and Thomas 2008; Walker et al. 2009; Oxenham and Cavill 2010). The results suggest general levels of anaemia were high, with $24.5 \%$ ( $n=29 / 118$ with orbits) of the delayed group, and $26.9 \%$ ( $n=75 / 279$ with orbits) of the non-delayed group showing grades 3-5 (Stuart-Macadam 1991). Cases of the most severe manifestation of the lesion, grade 5 , were slightly higher in the delayed group at $6.9 \%(n=2 / 29)$ compared to $4.0 \%(n=3 / 75)$. Direct study of lead levels in the teeth of the delayed group provides potential for future research. 


\section{Conclusions}

This study is the first attempt to directly measure the impact of chronic conditions on the growth and development of adolescents, using a large sample of individuals from medieval England. The results showed that those with recognisable chronic pathology were delayed in their pubertal attainment compared to their peers and that this delay increased with age. Peak height velocity and age of completion were the stages most influenced by illness, with those suffering from tuberculosis and treponemal disease significantly affected. While chronic conditions provide some explanation for the developmental delay seen in the medieval group, $20.3 \%$ of the individuals showed no evidence of disease. Some may have harboured hidden infections, but other factors such as malnutrition, poverty, physiological stress and exposure to urban environmental pollutants may have all contributed to this pattern and are difficult to measure in archaeological populations.

While the study sample did not reveal any females with delayed menarche, there was evidence that severe congenital conditions could play a part, with the potential for rickets to actually induce earlier menarche. However, the numbers of females for whom menarche can be assessed is limited by the poor preservation of the iliac crest epiphysis, and until further methods can be developed to identify menarcheal status, this type of research will continue to be hindered by small sample sizes. Overall, the study has demonstrated the potential of the pubertal status method to provide valuable information on the impact of environmental and disease stress in past populations.

\section{Acknowledgements}

The authors are grateful to many people for allowing us access to the skeletal material they curate: Rebecca Redfern, Jelena Bekvalac (Museum of London), Charlotte Roberts, Rebecca Gowland (University of Durham), Christine McDonnell (YAT), Natalie McCaul, Adam Parker (Yorkshire Museums Trust), Kevin Booth and Simon Mays (English Heritage). ML is especially grateful to Rob Hosfield (University of Reading) for his patience with the statistical advice, and the three anonymous reviewers for their insightful comments. This project was funded by the Leverhulme Trust (Grant number: F/0 0239/AM).

\section{References}

Albert A, and McCallister K. 2004. Estimating age at death from thoracic and lumbar vertebral ring epiphyseal union data. American Journal of Physical Anthropology 38:51.

Bean JA, Leeper JD, Wallace RB, Sherman BM, and Jagger H. 1979. Variations in the reporting of menstrual histories. American Journal of Epidemiology 109(2):181-185.

Bolton-Maggs P, and Thomas A. 2008. Disorders of the blood and bone marrow. In: McIntosh N, Helms P, Smyth R, and Logan S, editors. Forfar and Arneil's Textbook of Pediatrics. London: Churchill Livingstone. p 959-990.

Brabin L, and Brabin BJ. 1992. The cost of successful adolescent growth and development in girls in relation to iron and vitamin A status. American Journal of Clinical Nutrition 55(5):955-958. 
Brickley, M. and R. Ives 2008, The Bioarchaeology of Metabolic Bone Disease, Academic Press: Oxford.

Brimblecombe, P. 2011, The big smoke: a history of air pollution in London since medieval times, Routledge

Brown J, and Holden D. 2002. Iron acquisition by gram-positive bacterial pathogens. Microbes and Infection 4:1149-1156.

Buckley H, and Dias G. 2002. The distribution of skeletal lesions in treponemal disease: is the lymphatic system responsible? International Journal of Osteoarchaeology 12:178188.

Buehl C, and Pyle S. 1942. The use of age at first appearence of three ossification centers in determining the skeletal status of children. Journal of Pediatrics 21:335-342.

Buikstra JE, and Ubelaker D, editors. 1994. Standards for Data Collection from Human Skeletal Remains. Fayetteville: Arkansas Archeological Survey.

Chew A, and Harris SS. 2013. Does vitamin D affect timing of menarche? Nutrition reviews 71(3):189-193.

Connell B, Gray Jones A, Redfern R, and Walker D. 2012. A Bioarchaeological Study of Medieval Burials on the site of St Mary Spital. London: Museum of London Archaeology.

Coutinho S, Buschang P, and Miranda F. 1993. Relationships between mandibular canine calcification stages and skeletal maturity. American Journal of Orthodontics and Dentofacial Orthopedics 104(3):262-268.

Denham M, Schell LM, Deane G, Gallo MV, Ravenscroft J, and DeCaprio AP. 2005.

Relationship of lead, mercury, mirex, dichlorodiphenyldichloroethylene, hexachlorobenzene, and polychlorinated biphenyls to timing of menarche among Akwesasne Mohawk girls. Pediatrics 115(2):e127-e134.

Dreizen S, Spirakis CN, and Stone RE. 1967. A comparison of skeletal growth and maturation in undernourished and well-nourished girls before and after menarche. The Journal of Pediatrics 70(2):256-263.

EWEC WG. 2015. Realising the health and wellbeing of adolescents. In: Every Woman ECETCWWGoECD, editor. The Global Strategy from Women's, Children's and Adolescents' Health 20. http://www.everywomaneverychild.org/global-strategy2/news/1072-updating-the-global-strategy-working-papers.

Falys C, Schutkowski H, and Weston D. 2005. The distal humerus - a blind test of Rogers' sexing technique using a documented skeletal collection. Journal of Forensic Science 50(6):1289-1294.

Franchi L, Baccetti T, and McNamara J. 2000. Mandibular growth as related to cervical vertebral maturation and body height. American Journal of Orthodontics and Dentofacial Orthopedics 118(3):335-340.

Frisancho A, Garn S, and Rohnmann C. 1969. Age at menarche: a new method of predicting and retrospective assessment based on hand x-rays. Human Biology 41:42-50.

Gluckman P, and Hanson M. 2006. Evolution, development and timing of puberty. TRENDS in Endocrinology and Metabolism 17(1):7-12. 
Goldberg P. 1992. Women, Work, and Life Cycle in a Medieval Economy: Women in York and Yorkshire c. 1300-1520. Oxford: Clarendon Press.

Goodman AH. 1993. On the interpretation of health from skeletal remains. Current Anthropology 34(3):281-288.

Goyal R, Mehta P, and Kaur G. 2012. Nutritional status and menarche in adolescents of Punjab. Journal of Life Sciences 4(1):63-66.

Grave K, and Brown T. 1976. Skeletal ossification and the adolescent growth spurt. American Journal of Orthodontics 69(6):611-619.

Grunbaum J, Kann L, Kinchen S, Ross J, Hawkins J, Lowry R, Harris W, McManus T, Chyen D, and Collins J. 2004. Youth risk behavior surveillance--United States, 2003. MMWR: Surveillance Summaries 53(2):1-96.

Hägg U, and Taranger J. 1982. Maturation indicators and the pubertal growth spurt. American Journal of Orthodontics 82(4):299-309.

Hochberg Z, and Belsky J. 2013. Evo-devo of human adolescence: beyond disease models of early puberty. BMC Medicine 11(113):on-line journal.

Houston W. 1980. Relationships between skeletal maturity estimated from hand-wrist radiographs and the timing of the adolescent growth spurt. The European Journal of Orthodontics 2(2):81-93.

Kaplowitz P. 2008. Link between body fat and the timing of puberty. Pediatrics 121(208):1-8. Karapanou O, and Papadimitriou A. 2010. Determinants of menarche. Reproductive Biology and Endocrinology 8:115-122.

Lewis M. 2011. Tuberculosis in the non-adults from Romano-British Poundbury Camp, Dorset, England. International Journal of Paleopathology 1(1):12-23.

Lewis M, Shapland F, and Watts R. 2015. On the threshold of adulthood: A new approach for the use of maturation indicators to assess puberty in adolescents from medieval England. American Journal of Human Biology, DOI: 10.1002/ajhb.22761.

Liversidge HM, and Marsden PH. 2010. Estimating age and the likelihood of having attained 18 years of age using mandibular third molars. British Dental Journal 209(8):E13-E13.

Louis GMB, Gray LE, Marcus M, Ojeda SR, Pescovitz OH, Witchel SF, Sippell W, Abbott DH, Soto A, and Tyl RW. 2008. Environmental factors and puberty timing: expert panel research needs. Pediatrics 121(Supplement 3):S192-S207.

Marais B, Donald P, Gie R, Schaaf H, and Beyers N. 2005. Diversity of disease in childhood pulmonary tuberculosis. Annals of Tropical Paediatrics: International Child Health 25(2):79-86.

Marshall W, and Tanner J. 1969. Variations in pattern of pubertal changes in girls. Archives of Disease in Childhood 44(235):291.

Marshall WA, and Tanner JM. 1986. Puberty. In: Faulkner F, and Tanner JM, editors. Human Growth. New York: Plenum. p 171-209.

Mason A, Malik R, Bishop J, McGrogan P, and Ahmed S. 2011. Impact of inflammatory bowel disease on pubertal growth. Hormone Research Paediatrics on-line.

Mays S, Lees B, and Stevenson J. 1998. Age-dependent bone loss in the femur in a medieval population. International Journal of Osteoarchaeology 8(2):97-106. 
Millard A, Montgomery J, Trickett M, Beaumont J, Evans J, and Chenery S. 2014. Childhood lead exposure in the British Isles during the industrial revolution. In: Zuckerman $M$, editor. Modern Environmental and Human Health. New York: Wiley Blackwell. p 279300.

Moorrees CFA, Fanning EA, and Hunt EE. 1963. Age variation of formation stages for ten permanent teeth. Journal of Dental Research 42:1490-1502.

Ortner D. 2003. Identification of Pathological Conditions in Human Skeletal Remains. New York: Academic Press.

Oxenham M, and Cavill I. 2010. Porotic hyperostosis and cribra orbitalia: the erythropoietic response to iron-deficiency anaemia. Anthropological Science 118(3):199-200.

Patil RR. 2013. Determinants of leprosy with special focus on children: A socio-epidemiologic perspective. American Journal of Dermatology and Venereology 2(2):5-9.

Peng C-Y, Lee K, and Ingersoll G. 2002. An introduction to logistic regression analysis and reporting. Journal of Educational Research 96(1):3-14.

Philippaerts RM, Vaeyens R, Janssens M, Van Renterghem B, Matthys D, Craen R, Bourgois J, Vrijens J, Beunen G, and Malina RM. 2006. The relationship between peak height velocity and physical performance in youth soccer players. Journal of Sports Sciences 24(3):221-230.

Prebeg Ž, and Bralić I. 2000. Changes in menarcheal age in girls exposed to war conditions. American Journal of Human Biology 12(4):503-508.

Proos L, and Gustafsson J. 2012. Is early puberty triggered by catch-up growth following undernutrition? International Journal of Environmental Research and Public Health 9:1791-1809.

Rankin K, and Tuli S. 2009. Skeletal Tuberculosis. Children's Orthopaedics and Fractures 3(4):161-178.

Resnick D, and Kransdorf M. 2005. Bone and Joint Imaging. Third Edition. Philadelphia: Elsevier Saunders.

Roche A. 1976. Growth after puberty. In: Fuchs E, editor. Youth in a Changing World: crosscultural perspectives on adolescence. New York: Walter de Gruyter. p 8-17.

Saunders SR, and Hoppa RD. 1993. Growth deficit in survivors and non-survivors: biological mortality bias in subadult skeletal samples. Yearbook of Physical Anthropology 36:127-151.

Schaefer M, Black S, and Scheuer JL. 2009. Juvenile Osteology. London: Academic Press. Scheuer L, and Black S. 2000. Developmental Juvenile Osteology. London: Academic Press.

Selevan SG, Rice DC, Hogan KA, Euling SY, Pfahles-Hutchens A, and Bethel J. 2003. Blood lead concentration and delayed puberty in girls. New England Journal of Medicine 348(16):1527-1536.

Shapland F, and Lewis ME. 2013. Brief communication: A proposed osteological method for the estimation of pubertal stage in human skeletal remains. American Journal of Physical Anthropology 151(2):302-310.

Shapland F, and Lewis ME. 2014. A proposed method for the assessment of pubertal stage in human skeletal remains using cervical vertebrae maturation. American Journal of Physical Anthropology 153(1):144-153. 
Steinbock RT. 1976. Paleopathological Diagnosis and Interpretation: bone diseases in ancient human populations. Illinois: Charles $\mathrm{C}$ Thomas.

Stini WA. 1985. Growth rates and sexual dimorphism in evolutionary perspective. In: Gilbert $\mathrm{RI}$, and Mielke JH, editors. The Analysis of Prehistoric Diets. New York: Academic Press, Inc. : Harcourt Brace Jovanovich, publishers. p 191-226.

Stuart-Macadam PL. 1991. Anemia in Roman Britain: Poundbury Camp. In: Bush H, and Zvelebil M, editors. Health in Past Societies: Biocultural Interpretations of Human Skeletal Remains in Archaeological Contexts. Oxford: British Archaeological Research International Series. p 101-113.

Sutter R. 2003. Nonmetric subadult skeletal sexing traits: I. A blind test of the accuracy of eight previously proposed methods using prehistoric known-sex mummies for Northern Chile. Journal of Forensic Sciences 48(5):927-935.

Swenne I. 2008. Weight and growth requirements for menarche in teenage girls with eating disorders, weight loss and primary amenorrhea. Hormone Research 69(3):146-151.

Tanner J, Whitehouse R, Marshall W, Healy J, and Goldstein H. 1975. Assessment of Skeletal Maturity and Prediction of Adult Height. London: Academic Press.

Tsatsoulis A, Siamopoulou A, Petsoukis C, Challa A, Bairaktari E, and Seferiadis K. 1999. Study of growth hormone secretion and action in growth-retarded children with juvenile chronic arthritis (JCA). Growth Hormone \& IGF Research 9(2):143-149.

Thomas F, Renaud F, Benefice E, and de Meeus T. 2001. International variability of ages at menarche and menopause: patterns and main determinants. Human Biology 73(2):271-290.

Tyszka D. 2006. The Later History of Barton-on-Humber. Part Six. Church and People in a Victorian Country Town. Barton Parish 1830-1900. Gainsborough: Workers' Educational Association, GW Belton.

Ulijaszek SJ. 2006. The international growth standard for children and adolescents project: environmental influences on preadolescent and adolescent growth in weight and height. Food \& Nutrition Bulletin 27(Supplement 5):279-294.

Umlawska W, and Prusek-Dudkiewicz A. 2010. Growth retardation and delayed puberty in children and adolescents with juvenile idiopathic arthritis. Archives of Medical Science 1:19-23.

Van Noord P, and Kaaks Rv. 1991. The effect of wartime conditions and the 1944-45 'Dutch Famine' on recalled menarcheal age in participants of the DOM breast cancer screening project. Annals of Human Biology 18(1):57-70.

Villamor E, Chavarro J, and Caro L. 2009. Growing up under generalised violence: an ecological study of homicide rates and secular trends in age at menarche in Colombia, 1940s-1980s. Economics and Human Biology 7:238-245.

Villamor E, Marin C, Mora-Plazas M, and Baylin A. 2011. Vitamin D deficiency and age at menarche: a prospective study. American Journal of Clinical Nutrition 94(4):10201025.

Walker D. 2012. Disease in London, 1st-19th centuries. London: Museum of London Archaeology. 
Walker PL. 1994. Biases in preservation and sexism in sexing: some lessons from historical collections for paleodemographers. University of California, USA.

Walker PL, Bathurst R, Richman R, Gjerdrum T, and Andrushko V. 2009. The causes of porotic hyperostosis and cribra orbitalia: a reappraisal of the iron-deficiency anemia hypothesis. American Journal of Physical Anthropology 139:109-125.

Wareing J. 1980. Changes in the geographical distribution of recruitment of apprentices to the London companies 1486-1750. Journal of Historical Geography 6(3):241-249.

Wood JW, Milner GR, Harpending HC, and Weiss KM. 1992. The osteological paradox. problems of inferring prehistoric health from skeletal samples. Current Anthropology 33(4):343-370.

World Health Organisation W. 1993. The Health of Young People. A challange and a promise. Geneva: WHO.

Wu T, Buck G, and Mendola P. 2003. Blood lead levels and sexual maturation in U.S. girls: the third national health and nutrition examination survey, 1988-1994. Environmental Health Perspectives 111(5):737-741.

Youngs D. 2006. The Life-Cycle in Western Europe, C. 1300-1500: Manchester University Press.

Zacharias L, and Wurtman R. 1969. Age at menarche: genetic and environmental influences. New England Journal of Medicine 280:868-875.

Zhang K, Pollack S, Dicken C, Isaac B, Adel G, Zeitlian G, and Santoro N. 2008. Onset of ovulation after menarche in girls: a longitudinal study. Journal of Clinical Endocrinological Metabolism 93(4):1186-1194 
Supplementary Table: Estimated and expected pubertal stages for the total study sample.

\begin{tabular}{|c|c|c|c|c|c|c|}
\hline Site & Skeleton & Minimum age & $\begin{array}{l}\text { Puberty } \\
\text { Stage }\end{array}$ & $\begin{array}{l}\text { Pathology } \\
\text { Present }\end{array}$ & $\begin{array}{l}\text { Expected } \\
\text { Stage }\end{array}$ & $\begin{array}{l}\text { Puberty } \\
\text { Status }\end{array}$ \\
\hline Barton-on-Humber & 318 & 10 & 1 & No & 1 & not delayed \\
\hline Barton-on-Humber & 339 & 10 & 2 & No & 1 & not delayed \\
\hline Barton-on-Humber & 340 & 10 & 1 & No & 1 & not delayed \\
\hline Barton-on-Humber & 366 & 10 & 2 & No & 1 & not delayed \\
\hline Barton-on-Humber & 429 & 10 & 1 & No & 1 & not delayed \\
\hline Barton-on-Humber & 856 & 10 & 1 & No & 1 & not delayed \\
\hline Barton-on-Humber & 946 & 10 & 1 & No & 1 & not delayed \\
\hline Barton-on-Humber & 1206 & 10 & 1 & No & 1 & not delayed \\
\hline Barton-on-Humber & 1244 & 10 & 1 & No & 1 & not delayed \\
\hline Barton-on-Humber & 2250 & 10 & 3 & No & 1 & not delayed \\
\hline Barton-on-Humber & 2762 & 10 & 2 & No & 1 & not delayed \\
\hline St Helens & 5669 & 10 & 2 & No & 1 & not delayed \\
\hline St Helens & 5256 & 10 & 1 & No & 1 & not delayed \\
\hline St Helens & 5138 & 10 & 1 & No & 1 & not delayed \\
\hline St Helens & 6080 & 10 & 2 & No & 1 & not delayed \\
\hline St Helens & 5873 & 10 & 1 & No & 1 & not delayed \\
\hline St Mary Spital & 2923 & 10 & 1 & No & 1 & not delayed \\
\hline St Mary Spital & 2966 & 10 & 1 & No & 1 & not delayed \\
\hline St Mary Spital & 3492 & 10 & 2 & No & 1 & not delayed \\
\hline St Mary Spital & 3844 & 10 & 1 & No & 1 & not delayed \\
\hline St Mary Spital & 5705 & 10 & 1 & No & 1 & not delayed \\
\hline St Mary Spital & 5809 & 10 & 2 & No & 1 & not delayed \\
\hline St Mary Spital & 8181 & 10 & 1 & No & 1 & not delayed \\
\hline St Mary Spital & 9658 & 10 & 2 & No & 1 & not delayed \\
\hline St Mary Spital & 9845 & 10 & 1 & No & 1 & not delayed \\
\hline St Mary Spital & 10606 & 10 & 2 & No & 1 & not delayed \\
\hline St Mary Spital & 19120 & 10 & 1 & No & 1 & not delayed \\
\hline St Mary Spital & 19379 & 10 & 2 & No & 1 & not delayed \\
\hline St Mary Spital & 19441 & 10 & 1 & No & 1 & not delayed \\
\hline St Mary Spital & 20421 & 10 & 1 & No & 1 & not delayed \\
\hline St Mary Spital & 20446 & 10 & 1 & No & 1 & not delayed \\
\hline St Mary Spital & 20463 & 10 & 1 & No & 1 & not delayed \\
\hline St Mary Spital & 20924 & 10 & 2 & No & 1 & not delayed \\
\hline St Mary Spital & 21518 & 10 & 2 & No & 1 & not delayed \\
\hline St Mary Spital & 21730 & 10 & 2 & No & 1 & not delayed \\
\hline St Mary Spital & 21872 & 10 & 2 & No & 1 & not delayed \\
\hline St Mary Spital & 21969 & 10 & 2 & Yes & 1 & not delayed \\
\hline St Mary Spital & 21989 & 10 & 1 & No & 1 & not delayed \\
\hline St Mary Spital & 22253 & 10 & 1 & No & 1 & not delayed \\
\hline St Mary Spital & 22479 & 10 & 2 & No & 1 & not delayed \\
\hline St Mary Spital & 22898 & 10 & 2 & No & 1 & not delayed \\
\hline
\end{tabular}




\begin{tabular}{|c|c|c|c|c|c|c|}
\hline St Mary Spital & 23615 & 10 & 2 & No & 1 & not delayed \\
\hline St Mary Spital & 23948 & 10 & 2 & No & 1 & not delayed \\
\hline St Mary Spital & 24009 & 10 & 2 & No & 1 & not delayed \\
\hline St Mary Spital & 26496 & 10 & 2 & No & 1 & not delayed \\
\hline St Mary Spital & 27250 & 10 & 2 & No & 1 & not delayed \\
\hline St Mary Spital & 29297 & 10 & 2 & No & 1 & not delayed \\
\hline St Mary Spital & 30136 & 10 & 2 & No & 1 & not delayed \\
\hline St Mary Spital & 31004 & 10 & 2 & No & 1 & not delayed \\
\hline St Mary Spital & 31294 & 10 & 1 & No & 1 & not delayed \\
\hline St Mary Spital & 36026 & 10 & 1 & No & 1 & not delayed \\
\hline Barton-on-Humber & 230 & 11 & 3 & No & 1 & not delayed \\
\hline Barton-on-Humber & 514 & 11 & 3 & No & 1 & not delayed \\
\hline Barton-on-Humber & 1490 & 11 & 2 & No & 1 & not delayed \\
\hline Barton-on-Humber & 2650 & 11 & 1 & No & 1 & not delayed \\
\hline Fishergate House & 1518 & 11 & 1 & No & 1 & not delayed \\
\hline Fishergate House & 1106 & 11 & 2 & No & $\sqrt{3}$ & not delayed \\
\hline St Helens & 5771 & 11 & 1 & No & 1 & not delayed \\
\hline St Helens & 6034 & 11 & 1 & No & 1 & not delayed \\
\hline St Helens & 5751 & 11 & 1 & No & 1 & not delayed \\
\hline St Helens & 5510 & 11 & 2 & No & 1 & not delayed \\
\hline St Helens & 5782 & 11 & 3 & No & 1 & not delayed \\
\hline St Mary Spital & 3607 & 11 & 2 & No & 1 & not delayed \\
\hline St Mary Spital & 30702 & 11 & 2 & Yes & 1 & not delayed \\
\hline St Mary Spital & 3845 & 11 & 2 & No & 1 & not delayed \\
\hline St Mary Spital & 3933 & 11 & 1 & No & 1 & not delayed \\
\hline St Mary Spital & 5907 & 11 & 2 & Yes & 1 & not delayed \\
\hline St Mary Spital & 11187 & 110 & 2 & No & 1 & not delayed \\
\hline St Mary Spital & 14707 & 11 & 2 & No & 1 & not delayed \\
\hline St Mary Spital & 14724 & 11 & 3 & No & 1 & not delayed \\
\hline St Mary Spital & 15139 & 11 & 2 & No & 1 & not delayed \\
\hline St Mary Spital & 19171 & 11 & 2 & No & 1 & not delayed \\
\hline St Mary Spital & 19351 & 11 & 2 & No & 1 & not delayed \\
\hline St Mary Spital & 17397 & 11 & 2 & Yes & 1 & not delayed \\
\hline St Mary Spital & 19634 & 11 & 2 & No & 1 & not delayed \\
\hline St Mary Spital & 20910 & 11 & 2 & No & 1 & not delayed \\
\hline St Mary Spital & 20942 & 11 & 2 & No & 1 & not delayed \\
\hline St Mary Spital & 21413 & 11 & 1 & No & 1 & not delayed \\
\hline St Mary Spital & 21729 & 11 & 2 & No & 1 & not delayed \\
\hline St Mary Spital & 21957 & 11 & 2 & No & 1 & not delayed \\
\hline St Mary Spital & 22538 & 11 & 2 & No & 1 & not delayed \\
\hline St Mary Spital & 24136 & 11 & 2 & No & 1 & not delayed \\
\hline St Mary Spital & 29348 & 11 & 2 & No & 1 & not delayed \\
\hline St Mary Spital & 30074 & 11 & 1 & No & 1 & not delayed \\
\hline St Mary Spital & 31022 & 11 & 2 & No & 1 & not delayed \\
\hline
\end{tabular}




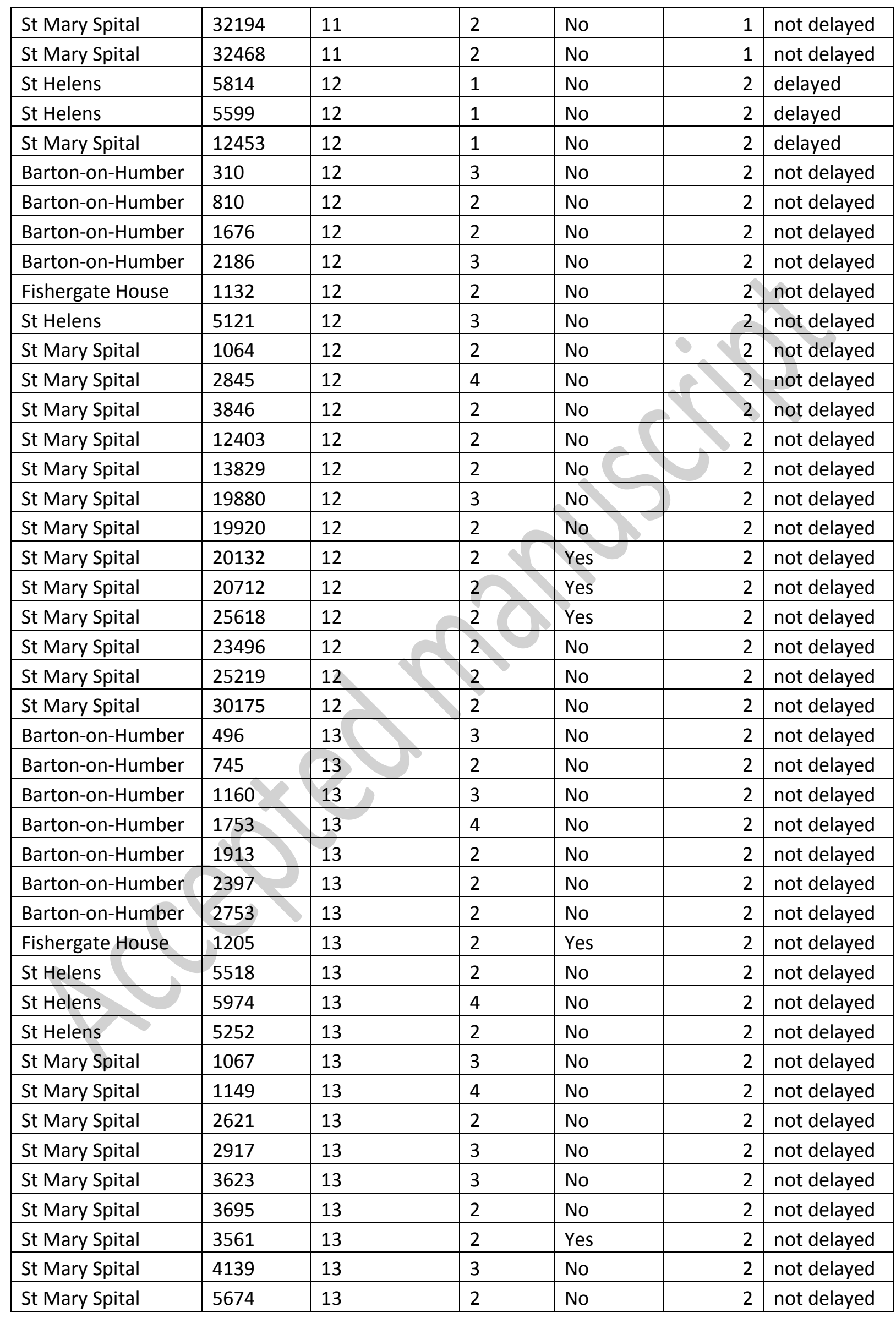




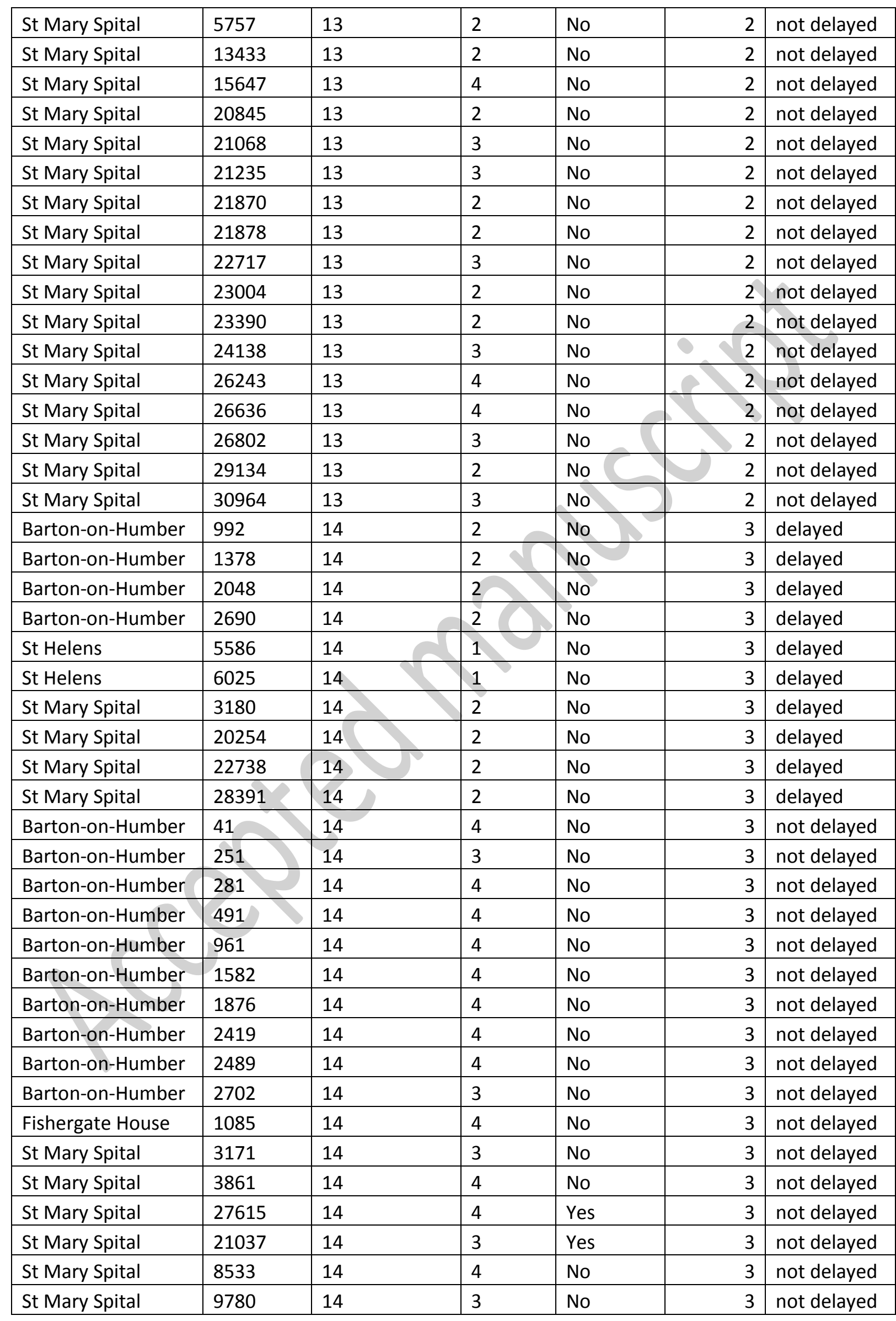




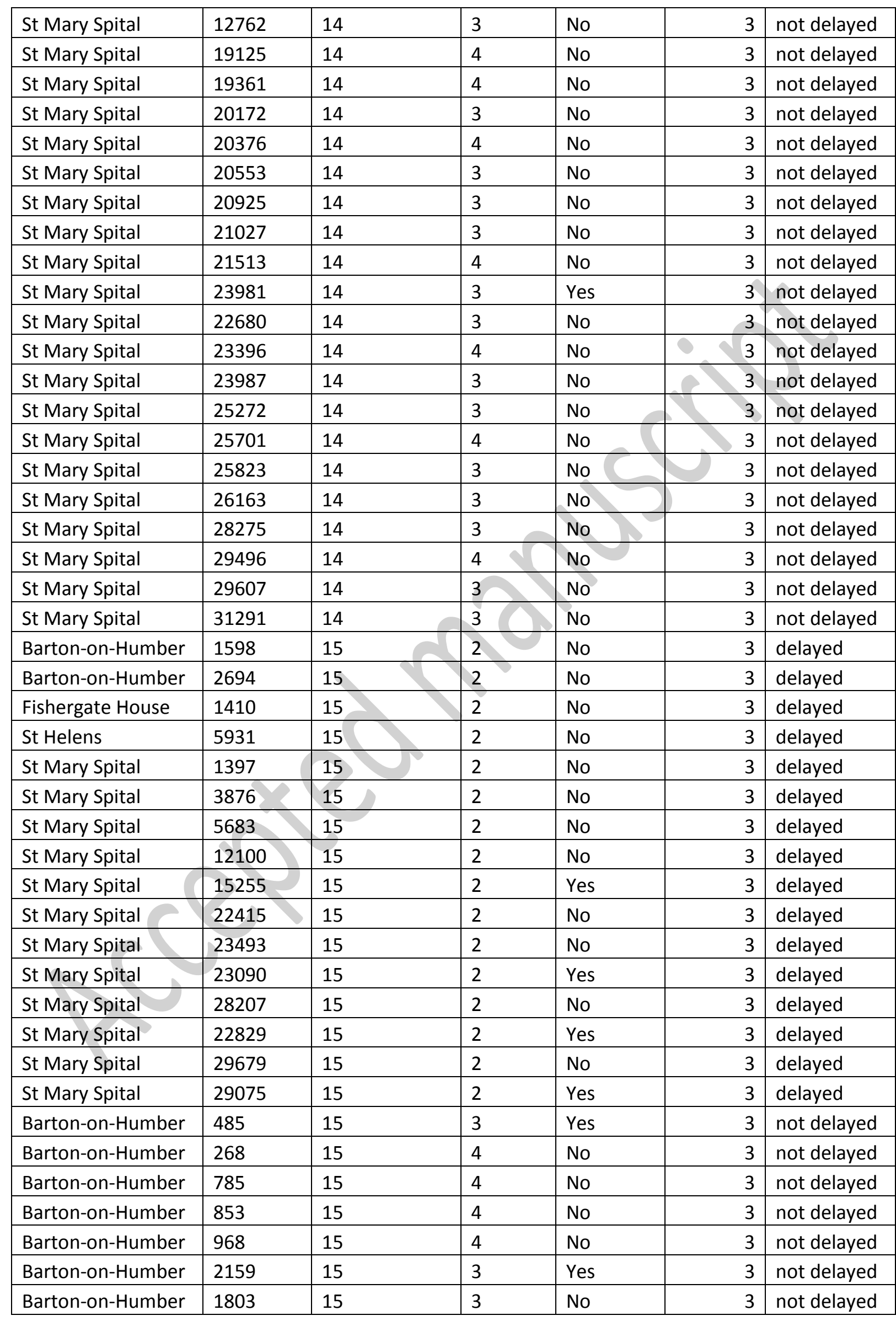




\begin{tabular}{|c|c|c|c|c|c|c|}
\hline Barton-on-Humber & 1820 & 15 & 4 & No & 3 & not delayed \\
\hline Barton-on-Humber & 2344 & 15 & 3 & No & 3 & not delayed \\
\hline Fishergate House & 1577 & 15 & 3 & No & 3 & not delayed \\
\hline Fishergate House & 1039 & 15 & 3 & No & 3 & not delayed \\
\hline Fishergate House & 1465 & 15 & 3 & No & 3 & not delayed \\
\hline St Helens & 5168 & 15 & 4 & No & 3 & not delayed \\
\hline St Helens & $5189 a$ & 15 & 4 & No & 3 & not delayed \\
\hline St Helens & 5224 & 15 & 3 & No & 3 & not delayed \\
\hline St Mary Spital & 2622 & 15 & 3 & No & 3 & not delayed \\
\hline St Mary Spital & 2967 & 15 & 3 & No & 3 & not delayed \\
\hline St Mary Spital & 3025 & 15 & 3 & No & 3 & not delayed \\
\hline St Mary Spital & 3083 & 15 & 4 & No & 3 & not delayed \\
\hline St Mary Spital & 3403 & 15 & 3 & No & 3 & not delayed \\
\hline St Mary Spital & 3491 & 15 & 4 & No & 3 & not delayed \\
\hline St Mary Spital & 3576 & 15 & 4 & No & 3 & not delayed \\
\hline St Mary Spital & 6355 & 15 & 3 & No & $\sqrt{3}$ & not delayed \\
\hline St Mary Spital & 6844 & 15 & 4 & No & 3 & not delayed \\
\hline St Mary Spital & 8355 & 15 & 3 & No & 3 & not delayed \\
\hline St Mary Spital & 10449 & 15 & 3 & No & 3 & not delayed \\
\hline St Mary Spital & 11395 & 15 & 4 & No & 3 & not delayed \\
\hline St Mary Spital & 12154 & 15 & 4 & No & 3 & not delayed \\
\hline St Mary Spital & 12819 & 15 & 4 & No & 3 & not delayed \\
\hline St Mary Spital & 12258 & 15 & 4 & Yes & 3 & not delayed \\
\hline St Mary Spital & 14838 & 15 & 4 & No & 3 & not delayed \\
\hline St Mary Spital & 13715 & 15 & 4 & Yes & 3 & not delayed \\
\hline St Mary Spital & 15261 & $15 \bigcirc$ & 3 & No & 3 & not delayed \\
\hline St Mary Spital & 15442 & 15 & 3 & No & 3 & not delayed \\
\hline St Mary Spital & 15584 & 15 & 4 & No & 3 & not delayed \\
\hline St Mary Spital & 17493 & 15 & 3 & No & 3 & not delayed \\
\hline St Mary Spital & 17544 & 15 & 3 & No & 3 & not delayed \\
\hline St Mary Spital & 19020 & 15 & 4 & No & 3 & not delayed \\
\hline St Mary Spital & 19250 & 15 & 4 & No & 3 & not delayed \\
\hline St Mary Spital & 19290 & 15 & 3 & No & 3 & not delayed \\
\hline St Mary Spital & 19481 & 15 & 4 & No & 3 & not delayed \\
\hline St Mary Spital & 19570 & 15 & 4 & No & 3 & not delayed \\
\hline St Mary Spital & 19915 & 15 & 4 & No & 3 & not delayed \\
\hline St Mary Spital & 20621 & 15 & 3 & Yes & 3 & not delayed \\
\hline St Mary Spital & 21111 & 15 & 3 & No & 3 & not delayed \\
\hline St Mary Spital & 21349 & 15 & 4 & No & 3 & not delayed \\
\hline St Mary Spital & 29986 & 15 & 3 & Yes & 3 & not delayed \\
\hline St Mary Spital & 22846 & 15 & 4 & No & 3 & not delayed \\
\hline St Mary Spital & 23161 & 15 & 4 & No & 3 & not delayed \\
\hline St Mary Spital & 24186 & 15 & 4 & No & 3 & not delayed \\
\hline St Mary Spital & 26188 & 15 & 3 & No & 3 & not delayed \\
\hline
\end{tabular}




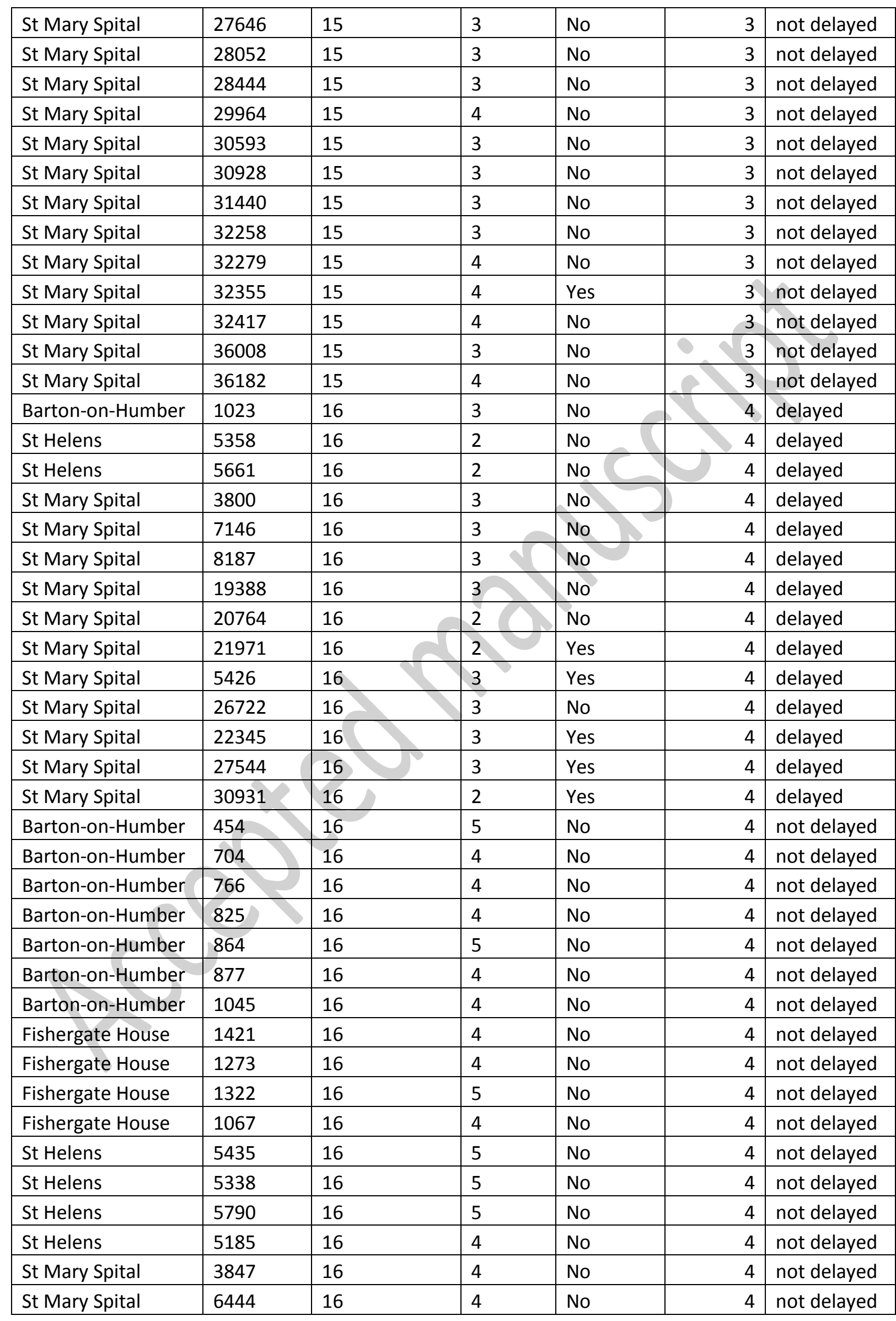




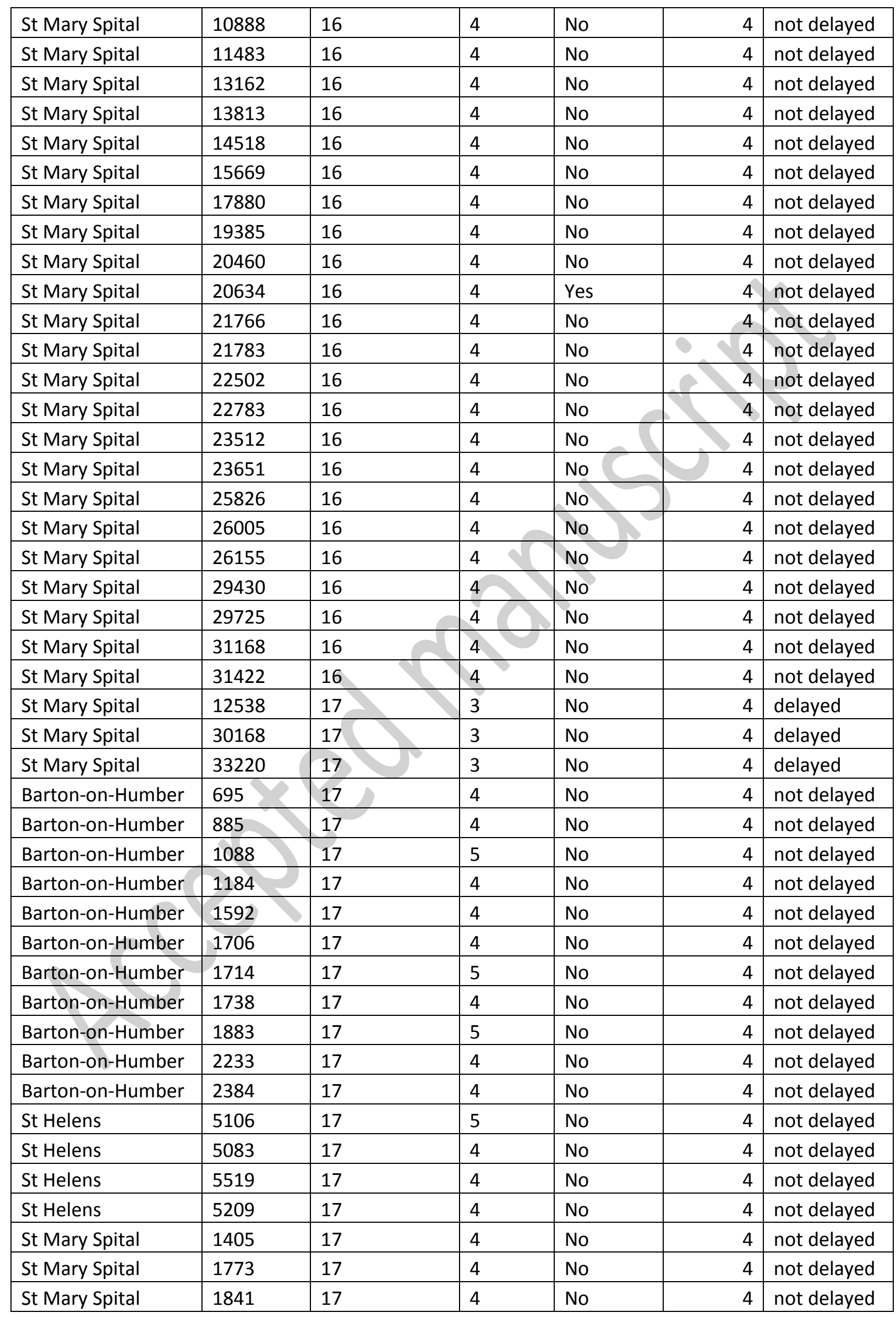




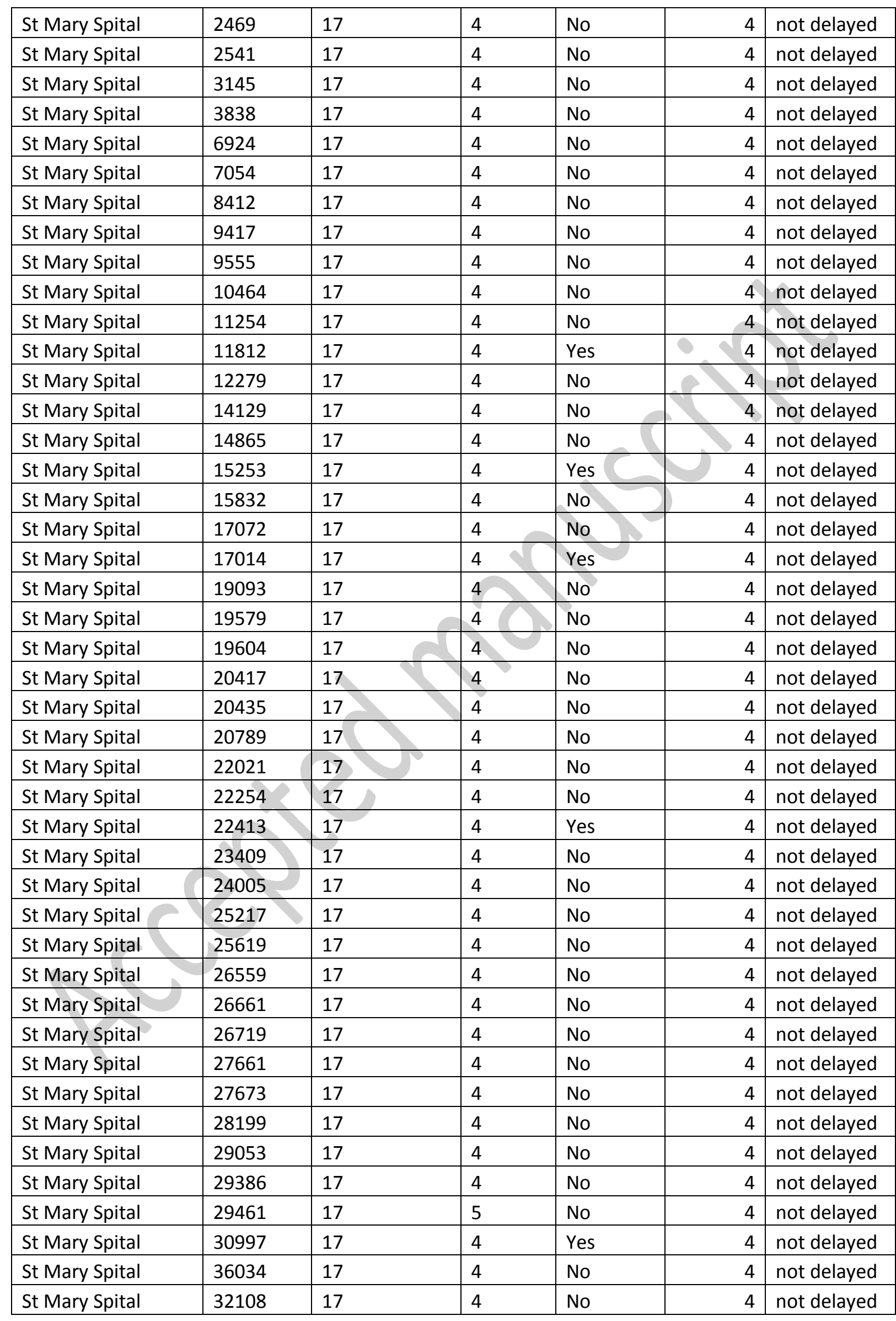




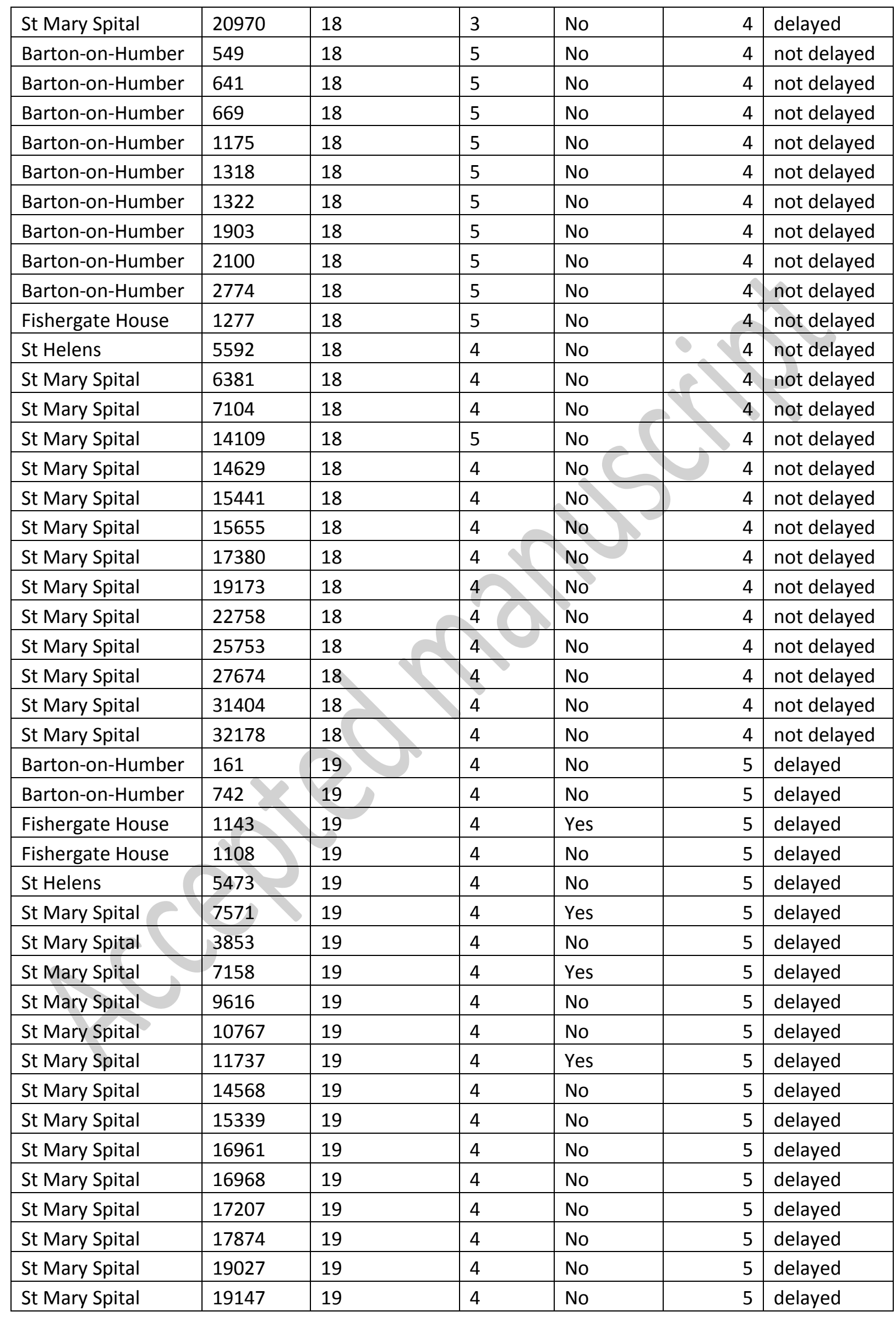




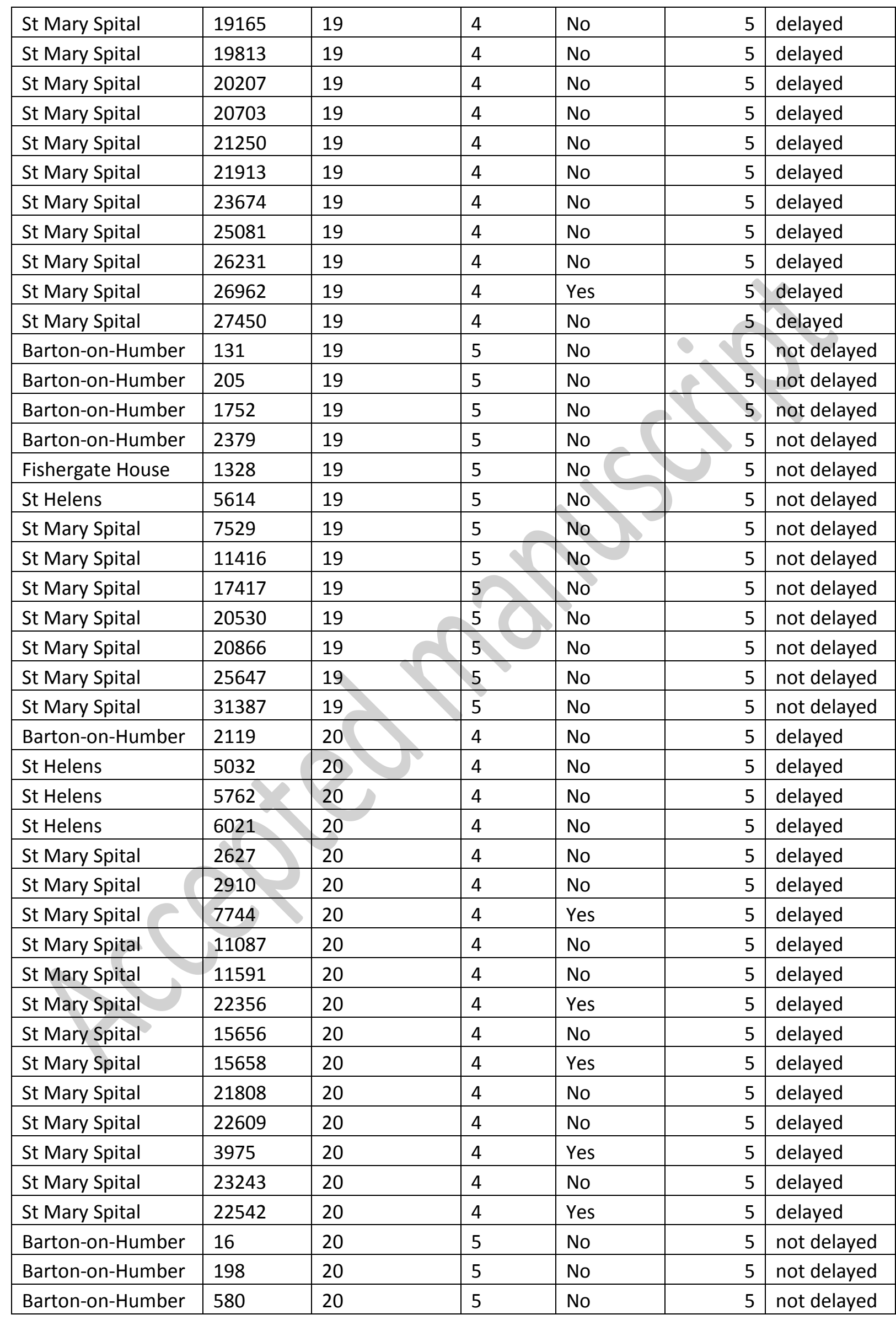




\begin{tabular}{|c|c|c|c|c|c|c|}
\hline Barton-on-Humber & 731 & 20 & 5 & No & 5 & not delayed \\
\hline Barton-on-Humber & 1006 & 20 & 5 & No & 5 & not delayed \\
\hline Barton-on-Humber & 1191 & 20 & 5 & No & 5 & not delayed \\
\hline Barton-on-Humber & 1640 & 20 & 5 & No & 5 & not delayed \\
\hline Barton-on-Humber & 1757 & 20 & 5 & No & 5 & not delayed \\
\hline Barton-on-Humber & 2178 & 20 & 5 & No & 5 & not delayed \\
\hline Barton-on-Humber & 2296 & 20 & 5 & No & 5 & not delayed \\
\hline Fishergate House & 1055 & 20 & 5 & No & 5 & not delayed \\
\hline Fishergate House & 1393 & 20 & 5 & No & 5 & not delayed \\
\hline St Helens & 5677 & 20 & 5 & No & 5 & not delayed \\
\hline Barton-on-Humber & 1042 & 22 & 4 & No & 5 & delayed \\
\hline St Helens & 5631 & 22 & 4 & No & 5 & delayed \\
\hline St Mary Spital & 3563 & 22 & 4 & No & 5 & delayed \\
\hline St Mary Spital & 6706 & 22 & 4 & No & 5 & delayed \\
\hline St Mary Spital & 7112 & 22 & 4 & No & 5 & delayed \\
\hline St Mary Spital & 7377 & 22 & 4 & No & 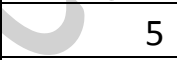 & delayed \\
\hline St Mary Spital & 8053 & 22 & 4 & No & 5 & delayed \\
\hline St Mary Spital & 8454 & 22 & 4 & No & 5 & delayed \\
\hline St Mary Spital & 9308 & 22 & 4 & No & 5 & delayed \\
\hline St Mary Spital & 10819 & 22 & 4 & No & 5 & delayed \\
\hline St Mary Spital & 10822 & 22 & 4 & No & 5 & delayed \\
\hline St Mary Spital & 11091 & 22 & 4 & No & 5 & delayed \\
\hline St Mary Spital & 12238 & 22 & 4 & No & 5 & delayed \\
\hline St Mary Spital & 13070 & 22 & 4 & No & 5 & delayed \\
\hline St Mary Spital & 13488 & 22 & 4 & No & 5 & delayed \\
\hline St Mary Spital & 3144 & 22 & 4 & Yes & 5 & delayed \\
\hline St Mary Spital & 14168 & 22 & 4 & No & 5 & delayed \\
\hline St Mary Spital & 14726 & 22 & 4 & No & 5 & delayed \\
\hline St Mary Spital & 13232 & 22 & 4 & Yes & 5 & delayed \\
\hline St Mary Spital & 19280 & 22 & 4 & No & 5 & delayed \\
\hline St Mary Spital & 19327 & 22 & 4 & No & 5 & delayed \\
\hline St Mary Spital & 19404 & 22 & 4 & No & 5 & delayed \\
\hline St Mary Spital & 15575 & 22 & 4 & Yes & 5 & delayed \\
\hline St Mary Spital & 20086 & 22 & 4 & Yes & 5 & delayed \\
\hline St Mary Spital & 20157 & 22 & 4 & No & 5 & delayed \\
\hline St Mary Spital & 21363 & 22 & 4 & No & 5 & delayed \\
\hline St Mary Spital & 21378 & 22 & 4 & No & 5 & delayed \\
\hline St Mary Spital & 21803 & 22 & 4 & No & 5 & delayed \\
\hline St Mary Spital & 21922 & 22 & 4 & No & 5 & delayed \\
\hline St Mary Spital & 21984 & 22 & 4 & No & 5 & delayed \\
\hline St Mary Spital & 22238 & 22 & 4 & No & 5 & delayed \\
\hline St Mary Spital & 19405 & 22 & 4 & Yes & 5 & delayed \\
\hline St Mary Spital & 22566 & 22 & 4 & No & 5 & delayed \\
\hline St Mary Spital & 22597 & 22 & 4 & No & 5 & delayed \\
\hline
\end{tabular}




\begin{tabular}{|c|c|c|c|c|c|c|}
\hline St Mary Spital & 23001 & 22 & 4 & No & 5 & delayed \\
\hline St Mary Spital & 24127 & 22 & 4 & No & 5 & delayed \\
\hline St Mary Spital & 26214 & 22 & 4 & No & 5 & delayed \\
\hline St Mary Spital & 26914 & 22 & 4 & No & 5 & delayed \\
\hline St Mary Spital & 28116 & 22 & 4 & No & 5 & delayed \\
\hline St Mary Spital & 29152 & 22 & 4 & No & 5 & delayed \\
\hline St Mary Spital & 30442 & 22 & 4 & No & 5 & delayed \\
\hline Barton-on-Humber & 1505 & 22 & 5 & Yes & 5 & not delayed \\
\hline Barton-on-Humber & 546 & 22 & 5 & No & 5 & not delayed \\
\hline Barton-on-Humber & 813 & 22 & 5 & No & 5 & not delayed \\
\hline Barton-on-Humber & 892 & 22 & 5 & No & 5 & not delayed \\
\hline Barton-on-Humber & 1044 & 22 & 5 & No & 5 & not delayed \\
\hline Barton-on-Humber & 1269 & 22 & 5 & No & 5 & not delayed \\
\hline Barton-on-Humber & 1295 & 22 & 5 & No & 5 & not delayed \\
\hline Barton-on-Humber & 1312 & 22 & 5 & No & 5 & not delayed \\
\hline Barton-on-Humber & 1779 & 22 & 5 & No & 3 & not delayed \\
\hline Barton-on-Humber & 1924 & 22 & 5 & No & 5 & not delayed \\
\hline Barton-on-Humber & 2252 & 22 & 5 & Yes & 5 & not delayed \\
\hline Barton-on-Humber & 2340 & 22 & 5 & No & 5 & not delayed \\
\hline Fishergate House & 1083 & 22 & 5 & No & 5 & not delayed \\
\hline Fishergate House & 1128 & 22 & 5 & No & 5 & not delayed \\
\hline Fishergate House & 1165 & 22 & 5 & No & 5 & not delayed \\
\hline St Helens & 5113 & 22 & 5 & Yes & 5 & not delayed \\
\hline St Helens & 5593 & 22 & 5 & No & 5 & not delayed \\
\hline St Helens & 5409 & 22 & 5 & Yes & 5 & not delayed \\
\hline St Helens & 6104 & 22 & 5 & No & 5 & not delayed \\
\hline St Helens & 5346 & 22 & 5 & No & 5 & not delayed \\
\hline St Helens & 5653 & 22 & 5 & No & 5 & not delayed \\
\hline St Helens & 5792 & 22 & 5 & No & 5 & not delayed \\
\hline St Helens & 5850 & 22 & 5 & No & 5 & not delayed \\
\hline St Helens & 5958 & 22 & 5 & No & 5 & not delayed \\
\hline St Mary Spital & 1055 & 22 & 5 & No & 5 & not delayed \\
\hline St Mary Spital & 1658 & 22 & 5 & No & 5 & not delayed \\
\hline St Mary Spital & 1857 & 22 & 5 & No & 5 & not delayed \\
\hline St Mary Spital & 2695 & 22 & 5 & No & 5 & not delayed \\
\hline St Mary Spital & 3289 & 22 & 5 & No & 5 & not delayed \\
\hline St Mary Spital & 1052 & 22 & 5 & Yes & 5 & not delayed \\
\hline St Mary Spital & 3483 & 22 & 5 & Yes & 5 & not delayed \\
\hline St Mary Spital & 3816 & 22 & 5 & No & 5 & not delayed \\
\hline St Mary Spital & 3903 & 22 & 5 & No & 5 & not delayed \\
\hline St Mary Spital & 7127 & 22 & 5 & No & 5 & not delayed \\
\hline St Mary Spital & 7001 & 22 & 5 & Yes & 5 & not delayed \\
\hline St Mary Spital & 7506 & 22 & 5 & No & 5 & not delayed \\
\hline St Mary Spital & $7659 a$ & 22 & 5 & No & 5 & not delayed \\
\hline
\end{tabular}




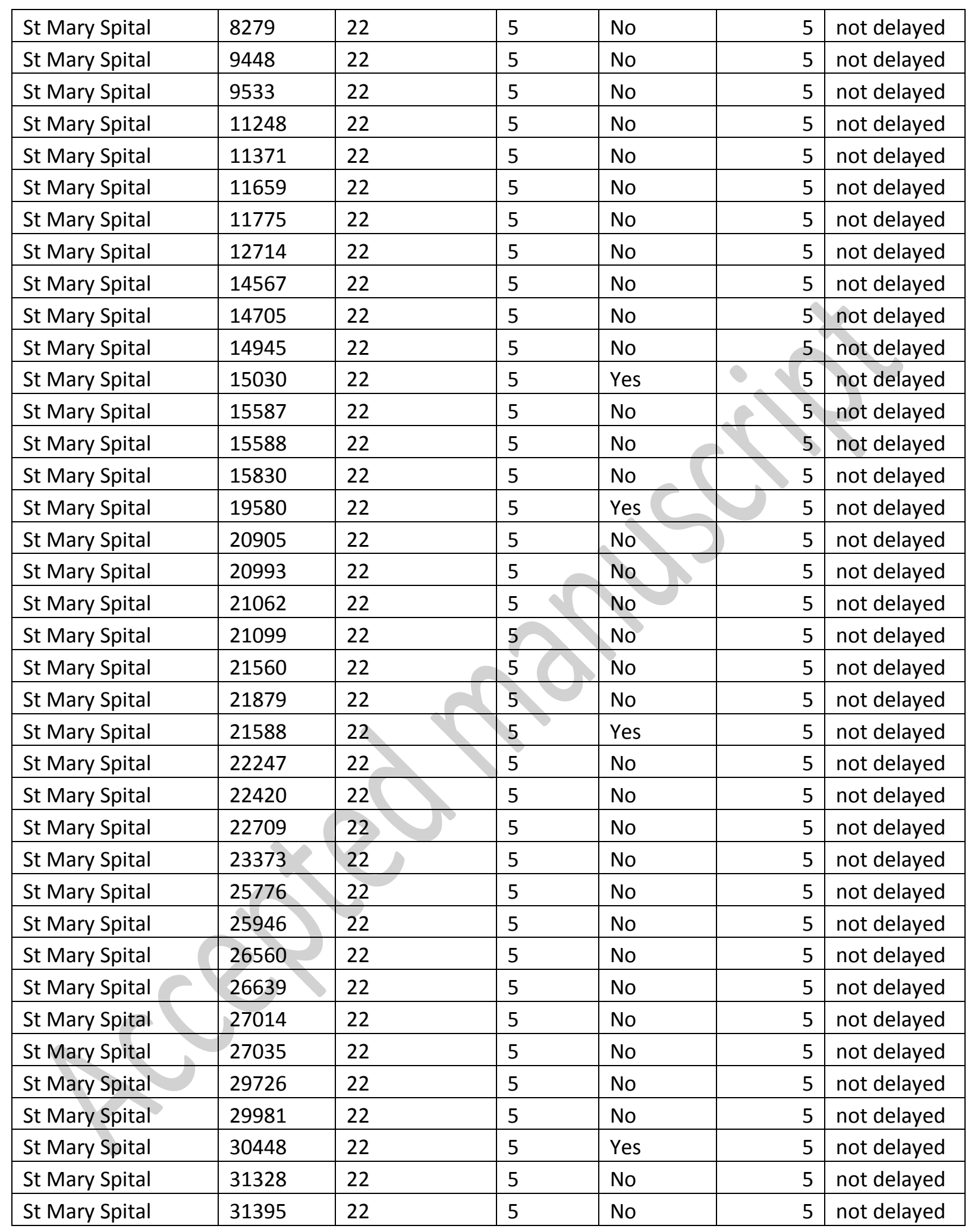

